\title{
What have we learned from molecular biology of paragangliomas and
}

\section{pheochromocytomas?}

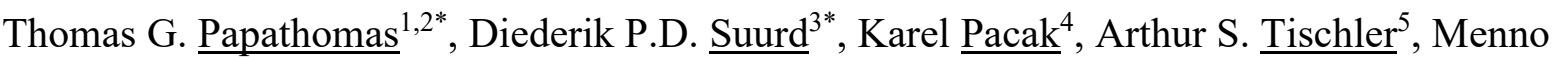

R. $\underline{\text { Vriens }}^{3}$, Alfred K. $\underline{\operatorname{Lam}}^{6,7,8^{* *}}$, Ronald R. de $\underline{\text { Krijger }}^{9,10^{* *}}$

${ }^{1}$ Institute of Metabolism and Systems Research, University of Birmingham, Birmingham,

United Kingdom.

${ }^{2}$ Gloucestershire Cellular Pathology Laboratory, Cheltenham General Hospital,

Gloucestershire Hospitals NHS Foundation Trust, Cheltenham, United Kingdom.

${ }^{3}$ Department of Surgical Oncology and Endocrine Surgery, University Medical Center

Utrecht, Utrecht, the Netherlands.

${ }^{4}$ Section on Medical Neuroendocrinology, Eunice Kennedy Shriver National Institute of Child

Health and Human Development, National Institutes of Health, Bethesda, Maryland, USA.

${ }^{5}$ Department of Pathology and Laboratory Medicine, Tufts Medical Center, Boston

Massachusetts, USA.

${ }^{6}$ School of Medicine, Griffith University, Gold Coast, Queensland, Australia.

${ }^{7}$ Pathology Queensland, Gold Coast University Hospital, Gold Coast, Queensland, Australia.

${ }^{8}$ Faculty of Medicine, The University of Queensland, Brisbane, Queensland, Australia.

${ }^{9}$ Princess Maxima Center for Pediatric Oncology, Utrecht, The Netherlands.

${ }^{10}$ Department of Pathology, University Medical Center Utrecht, Utrecht, the Netherlands.

*both authors should be regarded as first authors

**both authors are senior and corresponding authors

\section{Corresponding authors}

**Alfred K. Lam

Tel: +61756876543

Fax: +61756876797

E-mail: a.lam@griffith.edu.au

ORCID: orcid.org/0000-0003-2771-564X

**Ronald R. de Krijger

Tel: +31 889725628

E-mail: r.r.dekrijger-2@prinsesmaximacentrum.nl

\section{Word count: 7548}

Short title: Molecular biology of PPGL

Category: Literature review 


\begin{abstract}
Recent advances in molecular genetics and genomics have led to increased understanding of the aetiopathogenesis of pheochromocytomas and paragangliomas (PPGLs). Thus, pangenomic studies now provide a comprehensive integrated genomic analysis of PPGLs into distinct molecularly defined subtypes concordant with tumour genotypes. In addition, new embryological discoveries have refined the concept of how normal paraganglia develop, potentially establishing a developmental basis for genotype-phenotype correlations for PPGLs. The challenge for modern pathology is to translate these scientific discoveries into routine practice, which will be based largely on histopathology for the foreseeable future. Here, we review recent progress concerning the cell of origin and molecular pathogenesis of PPGLs, including pathogenetic mechanisms, genetic susceptibility and molecular classification. The current roles and tools of pathologists are considered from a histopathological perspective, including differential diagnoses, genotype-phenotype correlations and the use of immunohistochemistry in identifying hereditary predisposition and validating genetic variants of unknown significance. Current and potential molecular prognosticators are also presented with the hope that predictive molecular biomarkers will be integrated into risk stratification scoring systems to assess the metastatic potential of these intriguing neoplasms and identify potential drug targets.
\end{abstract}

Keywords: molecular biology; pheochromocytoma; paraganglioma; immunohistochemistry 


\section{Introduction}

Pheochromocytomas and paragangliomas (PPGLs) are neuroendocrine tumours originating from the adrenal medulla and extra-adrenal paraganglia, respectively. Pheochromocytomas (PCCs) are biochemically functional, producing epinephrine and/or norepinephrine, while sympathetic paragangliomas (PGLs) are almost always capable of catecholamine synthesis (i.e., norepinephrine and/or dopamine) but are often clinically silent. In contrast, parasympathetic PGLs are usually both biochemically and clinically silent given the usual lack of tyrosine hydroxylase, an enzyme required for catecholamine synthesis [1]. Parasympathetic PGLs are primarily located in the head and neck, while their sympathetic counterparts are located predominantly in the mediastinum, abdomen, and pelvis.

Paraganglionic tumours carry the highest degree of hereditability among all human neoplasms, given that approximately $40 \%$ are associated with a germline pathogenic mutation as opposed to $\leq 10 \%$ of other tumour types $[2,3]$. In recent decades, there has been a considerable increase in knowledge of the genes responsible for hereditary predisposition. The expanded spectrum of genes highlights the roles of Krebs cycle in the development of many PPGLs (Table 1). Germline mutations in succinate dehydrogenase $(S D H-x)$ genes (i.e. $S D H A$, $S D H B, S D H C, S D H D, S D H A F 2)$ are causally related to pathogenesis of PPGL as well as gastrointestinal stromal tumour (GIST), renal cell carcinoma (RCC) and pituitary adenoma [4]. Relatively recently, $S D H C$ epimutation and $S D H B$ mosaic mutation added to the $S D H$ genetic alterations associated with molecular pathogenesis of PPGL $[2,5]$. Krebs cycle-related PPGLs are currently regarded as the most aggressive paraganglionic tumours, with germline $S D H B$ mutations being among the strongest genetic risk factor for in development of metastatic PPGL. In addition, approximately $30 \%$ of 'sporadic' PPGL cases carry a somatic mutation in predisposing gene(s). Somatic mutations in other genes, i.e. ATRX, TP53, KMT2D, SETD2, 
and telomerase reverse transcriptase (TERT) promoter, might have a synergistic impact in tumourigenesis and clinical progression of PPGL [6-12].

In this review, we present molecular genetic advances on the cell of origin of PPGLs and discuss pathogenetic mechanisms associated with germline and/or somatic mutations in these tumours. Aspects of genetic susceptibility are also discussed in the context of molecular clusters (i.e. pseudohypoxia, kinase signalling and Wnt altered subtypes) associated with tumour genotypes and pathway activation. Molecular prognosticators including somatic driver events considered to be important for defining the risk for metastasis (e.g. transcriptional telomerase activation, somatic $A T R X$ mutations, MAML3 fusions) are also presented in the context of a continuously evolving field of endocrine molecular pathology.

The roles of pathologists and tools available to them are changing in step with molecular discoveries. From a histopathological perspective, new immunohistochemical tools are potentially available for refining differential diagnosis, focusing on genotype-phenotype correlations, identifying hereditary predisposition and validating genetic variants of unknown significance (VUS). Current and potential molecular prognosticators also offer the hope that predictive molecular biomarkers will be integrated into risk stratification scoring systems to assess the metastatic potential of these intriguing neoplasms and identify potential drug targets. 


\section{Novel Concepts on Cell of Origin}

Traditionally, PPGLs have been regarded as straightforwardly neural-crest derived neoplasms arising from the adrenal medulla and extra-adrenal paraganglia [13]. Novel experimental evidence has recently challenged the developmental background of the cell of origin of adrenal medulla and paraganglia, suggesting that peripheral nerves may serve as a stem cell niche for neuroendocrine system development [14]. Peripheral glial stem cells, termed nerve-associated Schwann cell precursors (SCPs), have been shown to generate chromaffin cells via an intermediate progenitor cell type characterized by a specific transcriptional program [14]. Not only do multipotent SCPs propagate to chromaffin cells, but also to mesenchymal stem cells, Schwann cells, endoneurial fibroblasts, and melanocytes, which migrate along the peripheral nerves to reach specific sites within the developing embryo [15]. Utilising a combination of lineage tracing strategies with nerve- and cell type-specific ablations during embryonic mouse development, the role of SCPs has been extended to organ of Zuckerkandl [16] and carotid body [17], but they seem to contribute less to the sympathetic paraganglia around the dorsal aorta [16].

Differences in origin of chromaffin cell lineage (i.e. SCP-derived adrenal medulla/ organ of Zuckerkandl organ) and sympathetic cell lineage (i.e. mostly neural crest-derived sympathetic paraganglia) might indicate different cells of origin of PCC, PGL and neuroblastoma $[14,16]$. This may also explain differences in biological behaviour and genetic backgrounds related to those intriguing neoplasms [15]. Nevertheless, susceptibility genes causally related both to paraganglionic and neuroblastic neoplasms (i.e. KIF1B $\beta, M A X, S D H A$; Table 1) [18-21], along with composite tumours that contain chromaffin cells and neurons [22], point towards a common or strongly related progenitor cell in a subset of cases [23]. Though the concept of SCP is a major modification of the traditional developmental model, the neural crest connection is not completely gone. Sympathetic neurons are derived from progenitors 
that delaminate from the neural crest and migrate directly to their destinations. On the other hand, SCPs form from neural crest-derived precursors that essentially remain in place, then migrate along the axons of dorsal root ganglion neurons, join with preganglionic sympathetic axons emerging from the spinal cord and migrate along those axons to reach developing paraganglia [14].

Phenylethanolamine-N-methyltransferase (PNMT) gene encodes for phenylethanolamine-N-methyltransferase enzyme, catalysing the conversion of norepinephrine to epinephrine. Different chromaffin cell types (i.e. adrenergic versus noradrenergic) can be distinguished based on PNMT levels [24, 25]. Utilising PNMT mRNA expression as a marker of chromaffin cell type, the Cancer Genome Atlas (TCGA) PPGL cohort was investigated in the context of chromaffin cell biology [26]. Three PPGL subgroups subsequently emerged: (i) a $P N M T^{\text {high }}$ subset almost exclusively occurring in the adrenal medulla and significantly associated with epinephrine/metanephrine production and subsequent secretion almost exclusively in the kinase-signalling mRNA subtype; (ii) a $P N M T^{\text {low } / \text { vesicle monoamine }}$ transporter $(V M A T)^{\text {high }}$ subset occurring in both adrenal and extra-adrenal sites and significantly associated with norepinephrine/normetanephrine production and subsequent secretion in the pseudohypoxia mRNA subtype; and (iii) a $P N M T^{\text {low }} / V M A T^{\text {low }}$ subset occurring predominantly in the adrenal medulla and associated with production and secretion of a mixture of catecholamines and their metabolites which mainly but not exclusively with the Wnt-altered mRNA subtype (Table 2) [26].

Accordingly, it has been postulated that subgroups (i) and (ii) have an adrenergic chromaffin cell-like and sympathetic neuron-like origin, respectively, while subgroup (iii) originates from earlier stages during chromaffin cell development, i.e. committed sympathoadrenal progenitor-like origin $[23,26]$. From a biological and therapeutic perspective, 
future research is warranted to elucidate and specify tumour-initiating cells, including cancer stem cells, in the tumourigenesis of PPGL. 


\section{Molecular Genetics and Genomics in PPGL Pathogenesis}

\section{Molecular mechanisms in PPGL tumourigenesis}

PPGLs as neuroendocrine tumours are characterized by strong genetic determinism with approximately $40 \%$ of patients with PPGLs harbouring germline mutation and at least $30 \%$ of the remaining 'sporadic' cases carrying a somatic mutation in predisposing gene(s) [27-29].

Over the last 20 years, our knowledge of hereditary predisposition of PPGL has rapidly expanded from three (i.e. VHL, RET and NF1) to over 20 PPGL susceptibility genes. While only 17 predisposing genes are listed in the most updated version of World Health Organisation (WHO) Classification of Tumours of Endocrine Organs [22], the catalogue of genes implicated in the molecular pathogenesis is gradually expanding (Table 2). This encompasses tumoursuppressor genes and proto-oncogenes of low mutational frequencies reported only on the germline, germline and somatic, or only at the somatic level [2].

New DNA sequencing technologies have led to the discovery of several new predisposing genes implicated in mitochondrial metabolism, DNA methylation and mitogenactivated protein kinase (MAPK) signalling pathways [28-30]. These encompass $M D H 2$ gene encoding for malate dehydrogenase type 2, a mitochondrial enzyme of the Krebs cycle oxidizing L-malate to oxaloacetate; DLST gene encoding for dihydrolipoamide Ssuccinyltransferase, an E2 subunit of mitochondrial 2-oxoglutarate dehydrogenase complex catalysing the conversion of alpha ketoglutarate to succinyl-CoA; SLC25A11 gene encoding for the 2-oxoglutarate/malate carrier involved in the malate aspartate shuttle; DNMT3A gene encoding a DNA methyltransferase establishing DNA methylation patterns; $H 3 F 3 A$ gene encoding for Histone H3.3, a protein essential in maintaining genome integrity during mammalian development; MERTK gene encoding for proto-oncogene tyrosine-protein kinase MER, an enzyme regulating cell survival and phagocytosis of apoptotic cells; and MET gene encoding for c-Met protein, which possesses tyrosine kinase activity. 
In parallel, a genomic approach based on whole-genome DNA methylation assessment with subsequent exome sequencing of Krebs cycle genes has identified new candidate genes, namely $I D H 3 B$ and $G O T 2$. IDH3B encodes the beta subunit of NAD-specific isocitrate dehydrogenase 3 (IDH3) catalysing the oxidation of isocitrate to $\alpha$-ketoglutarate, whereas GOT2 encodes glutamic-oxaloacetic transaminase 2 (GOT2), a mitochondrial enzyme converting oxaloacetate into aspartate by transamination, with the consequent conversion of glutamate to $\alpha$-ketoglutarate [31].

An additional screening strategy based on metabolome-guided genomics (or energy pathway metabologenomics [32]) revealed the first ever identified patient with an Isocitrate Dehydrogenase 2 (IDH2)-mutated PPGL accompanied by a large increase in 2hydroxygluturate in neoplastic tissue among others with Isocitrate Dehydrogenase 1 (IDH1)and Fumarate Hydratase (FH)-mutated counterparts [33]. In fact, targeted metabolomics (i.e. succinate:fumarate ratio, fumarate:malate ratio and 2-hydroxyglutarate levels in tumour tissue) could be a valuable tool to identify $S D H-x, F H$ and $I D H$ pathogenic variants, respectively. Mass spectrometric analysis of biochemical imbalances by liquid Chromatography (LC)-mass spectrometry displayed a higher succinate:fumarate ratio in SDH-deficient PPGLs, GISTs and RCCs compared to their SDH-proficient counterparts [34]. Detection of succinate utilising magnetic resonance spectrometry $\left({ }^{1} \mathrm{H}-\mathrm{MRS}\right)$ also appears a highly specific and sensitive hallmark of SDH-deficiency in PPGLs [35].

Even though paraganglionic tumours are characterised by a low mutational load and mutual exclusion between most pathogenic mutations, whole exome sequencing (WES) and/or targeted next generation sequencing (NGS) have revealed double germline mutations (i.e. Multilocus Inherited Neoplasia Alleles Syndrome [36]). To exemplify, SDHC and PTEN germline mutations were documented in a patient suffering from carotid PGLs and multifocal papillary thyroid carcinoma [37]. In addition, another patient with head and neck PGL 
harboured $S D H B$ and $C H E K 2$ germline mutations; the latter known to be causally related to hereditary breast and ovarian carcinoma [38]. Furthermore, a comprehensive cancerpredisposition gene testing in an adult multiple primary tumour series revealed an individual carrying $M A X$ and $F H$ mutations in the germline and suffering from bilateral PCCs without any reported familial history of neoplasia[39]. Simultaneous occurrence of SDHB and TP53 germline mutations has been recently reported in a patient with metastatic PCC [40].

At the somatic level, $H R A S$ mutations do not co-occur with other germline mutations $[38,41-44]$, whereas other somatic variants have been documented to co-segregate, e.g. ATRX with $S D H-x / F H / V H L / R E T / N F 1$ mutations [7, 8, 38, 45, 46], MYO5B/VCL/MYCN with $S D H B$ mutations [47], KDM2B/TP53 with $S D H B$ mutations [8, 9] and TERT promoter mutations with $S D H-x$ mutations $[10,11]$. Such co-occurrence(s) might have a synergistic effect on driver mutations and hence co-segregation of susceptibility mutations and/or overlapping structural alterations among tumours of different genetic backgrounds could play a role in tumour progression [2]. Somatic ATRX mutations as well as genomic alterations related to transcriptional TERT activation (i.e. TERT promoter mutations or hypermethylation and structural TERT rearrangement or amplification of TERT locus) confer information on metastatic progression and poor prognosis of patients with Krebs cycle-associated paraganglionic tumours [48]. Moreover, somatic $M Y O 5 B$ mutations leading to deregulated Rab and Rac/Rho GTPase pathways which appear to be preferentially enriched in PPGL-affected patients with metastatic disease and germline $S D H B$ mutations $[47,49]$.

In addition to germline and/or somatic mutations, diverse mechanisms influence tumourigenesis of PPGL through a broad range of biological pathways i.e. mitochondrial metabolism, chromatin remodelling, cell cycle regulation as well as MAPK, mTOR, MYC and Wnt/b-catenin signalling pathways [28, 30]. These mechanisms encompass recurrent copy number changes (i.e. 9q, 17q, 19p13.3 and 20q gains; 1p/3q, 11p, 11q, 6q, 17p, 22 losses), 
fusions, epigenetic aberrations in $S D H$ - and $F H$-related tumours, aberrant hypermethylation of the promoter region of $S D H C$ gene (or $S D H C$ epimutations), post-zygotic mosaicism as well as transcriptional dysregulations $[8,9,53-55,22,31,41,45,46,50-52]$.

The TCGA project $[26,46]$ identified novel genomic alterations, i.e. somatic cold shock domain containing E1 (CSDE1) mutations and somatic fusions involving Mastermind Like Transcriptional Coactivator 3 (MAML3), NF1, BRAF and NGFR genes; confirmed biomarkers, i.e. pseudohypoxia subtype, germline $S D H B$ mutations, and somatic ATRX mutations; and classified PPGLs into four molecularly defined groups: (i) pseudohypoxia subtype, (ii) kinase signalling subtype, (iii) Wnt-altered subtype, driven by $M A M L 3$ fusion and CSDE1 mutation, and (iv) cortical admixture subtype, most likely representing adrenal cortical contamination [6]. However, all paraganglionic tumours harbouring germline $M A X$ mutations were detected in the latter subgroup suggesting that cortical admixture subtype might be driven by distinct biology [26]. The subtypes do not share common cellular or biological behaviour and with genome doubling occurring preferentially in pseudohypoxic $V H L$ - and $E P A S I / H I F 2 A$ related tumours and pseudohypoxic Krebs cycle-related tumours being the most clinically aggressive PPGLs respectively [6, 26].

The TCGA study followed a comprehensive integrated genomic analysis which classified PPGLs into five molecularly defined groups with distinct driver mutations, expression signatures, copy number changes, DNA methylation alterations, and miRNA dysregulations, as follows: (i) cluster $\mathrm{C} 1 \mathrm{~A}$ including $S D H-x$ - and $F H$-mutated tumours; (ii) cluster C1B comprising VHL-mutated tumours; (iii) cluster $\mathrm{C} 2 \mathrm{~A}$ encompassing tumours harbouring RET, NF1, TMEM127, MAX, and HRAS mutations; (iv) cluster C2B comprising MET-mutated tumours; and (v) cluster $\mathrm{C} 2 \mathrm{C}$ with clusters $\mathrm{C} 2 \mathrm{~B}$ and $\mathrm{C} 2 \mathrm{C}$ being enriched in sporadic tumours $[8,27]$. This expanded the initial transcription profile-based classification, which was composed of a pseudohypoxic cluster 1 and a kinase receptor-signalling cluster 2 
[56]. A strong concordance between gene-expression of PPGL subtypes and tumour genotype has been subsequently confirmed [57] with EPAS1/HIF2A-mutated tumours exhibiting a characteristic expression signature within the pseudohypoxic cluster 1 [58]. Nevertheless, a considerable proportion of tumours analysed at the transcriptomic level lacks any susceptibility mutation(s) in known PPGL genes [29].

Transcriptome-based classification of PPGLs into pseudohypoxic cluster 1, kinase signalling cluster 2 , and Wnt altered cluster 3 impacts on distinct molecular pathways and down-stream targets (Table 2) [6, 14, 63, 26, 28, 29, 46, 59-62].

- Cluster 1 is characterized by activation of pseudohypoxic pathways with resultant activation of HIF- $\alpha$ target genes implicated in angiogenesis, cell proliferation, survival and epithelial-mesenchymal transition (Figure 1A). In the SDH-/ FH-deficient and mutant IDH state, oncometabolite accumulation lead to inhibition of the ten-eleven translocation (TET) enzymes and Jumonji domain histone demethylases causing overall DNA hypermethylation among other epigenetic modifications, which impact on several genes involved in epithelial-mesenchymal transition as well as chromaffin differentiation. Synergistic roles of TET repression and pseudohypoxia have been recently revealed in the acquisition of metastatic traits.

- Cluster 2 is associated with abnormal activation of kinase signalling pathways, i.e. the RAS/RAF/ERK, PI3Kinase/AKT/mTOR and MYC/MAX/MXD1 pathways (Figure 1B), and DNA hypomethylation linked to a higher number of somatic copy number aberrations. Haploinsufficient tumour suppressor gene $K I F 1 B \beta$ acts downstream of the nerve growth factor (NGF) pathway and appears to play a significant role in intrinsic mitochondria-mediated apoptosis via the regulation of structural and functional dynamics of mitochondria. Dysregulation of KIF1B $/$ mitochondrial metalloprotease YME1L1/ mitochondrial GTPase OPA1 mechanism might be involved in malignant 
potential of neural crest-derived neoplasms including paraganglionic and neuroblastic tumours.

- Cluster 3 is characterized by Wnt/b-catenin pathway activation, which along with Sonic Hedgehog pathway expression is associated with chromaffin cell differentiation and DNA hypomethylation.

RNA sequencing (RNAseq) analysis data from TCGA and Therapeutically Applicable Research to Generate Effective Treatments (TARGET) cohorts including 3,319 tumour samples originating from 35 different tumour types have challenged the current clinicopathological classification as PPGLs clustered with pancreatic neuroendocrine tumours and neuroblastomas [64]. Nevertheless, in-depth characterization of long intergenic noncoding RNA (lincRNA) expression profiles has recently displayed not only a specific lincRNA profile in PPGLs from a pan-cancer perspective but also five emerging molecular subtypes corresponding to the established molecular classification of PPGL[52]. Another study identified four long noncoding RNA-based (lncRNA) subtypes which strongly correlated with mRNA expression clusters and accordingly extending the spectrum of transcriptional dysregulations in PPGLs to long non-coding RNAs [53].

Circular RNA (circRNA) expression profiling has been explored in paraganglionic tumours with findings indicating that altered circRNAs regulate histone methylation processes. circRNA-miRNA-mRNA coding-noncoding gene co-expression (CNC) networks were mapped. Accordingly, interactions of circRNAs with their target miRNAs were shown to regulate histone methylation and hence influence PPGL pathogenesis [54].

High-throughput miRNA profiling analyses have identified miRNAs that have molecular and functional roles in tumourigenesis and/or clinical progression of PPGL. An integrative study of miRNome, transcriptome and proteome identified a signature of 6 miRNAs 
(i.e. $\operatorname{miR}-21-3 p$, miR-183-5p, miR-182-5p, miR-96-5p, miR-551b-3p, and miR-202-5p) being associated with metastatic risk and time to progression as well as highlighted combined expression of miR-21-3p/miR-183-5p with the highest predictive power for metastasis in PPGL. This expression was also associated in vitro with pro-metastatic features, that is neuroendocrine-mesenchymal transition phenotype and increased cell migration rate [55]. The study further supported the findings emerging from previous miRNA analyses on the role of the miR-183 cluster (miR-96/182/183) in metastatic progression of PCCs [65, 66].

\section{Genetic susceptibility}

An autosomal dominant pattern of inheritance is linked to germline mutations in almost all PPGL susceptibility genes [67]. Of note is a parent-of-origin expression phenotype documented via the paternal line in $S D H D$-, $S D H A F 2$ - and $M A X$-related cases [68]. Rare reports of $S D H D$-related PCC dependent on inheritance via the maternal line are also noted [69, 70]. Gain-of-function mutations in RET, MET, MERTK, EPAS1/HIF2A, GOT2 and DNMT3A oncogenes do not require a second hit, while inactivation or loss of the wild-type allele is present in the setting of tumour suppressor gene(s).

Most EPASI/HIF2A mutations associated with PPGL tumourigenesis are somatic or mosaic [71], while $S D H B$ mutations occur almost always in the germline, with somatic [4] or mosaic counterparts [5] being rather rare genetic events. A sporadic genetic disorder potentially characterized by mosaicism is the Carney Triad, characterised by tumours affecting at least five organs, but always encompassing gastric GIST, PPGL, and pulmonary chondroma. In some patients, adrenocortical adenoma and oesophageal leiomyoma may occur [2, 72, 73]. Even though $10 \%$ of Carney Triad patients harbour germline $S D H A$, SDHB or $S D H C$ variants [74], most cases display SDH down-regulation through $S D H C$ promoter hypermethylation $[51,75$, 76]. Germline and/or somatic mosaicism for site-specific aberrant $S D H C$ hypermethylation has 
been reported both in patients suffering from PCC and GIST [31] as well as PGL and adrenocortical adenoma [50]. Postzygotic mosaic mutation in $H 3 F 3 A$ gene has recently been recognised to be associated with paraganglionic tumours and aggressive giant cell tumour of bone in a non-familial PPGL syndromic context [9]. The aforementioned PPGL related genes mutated postzygotically, but prior to terminal differentiation, and expand the mosaicism-related spectrum of endocrine tumour syndromes such as McCune-Albright syndrome and neurofibromatosis type 1 (NF1) [22]. Identifying germline or somatic mosaic disruptions has implications for risk assessment as well as genetic testing and counselling in PPGL-affected families.

The diverse genetic backgrounds correlate with differences not only in modes of inheritance and penetrance, but also in clinical presentation, tumour distribution and biological behaviour [2]. This is in accordance with the aforementioned cell of origin model based on the TCGA cohort [26]. To exemplify, extra-adrenal sympathetic PGLs are most frequently associated with $S D H D$ and $S D H B$ mutations, while head and neck parasympathetic PGLs usually harbour $S D H D, S D H B$ or rarely $S D H C$ mutations. On the other hand, PCCs are more often associated with RET, NF1, TMEM127, MAX, and VHL mutations [77]. Within the pseudohypoxic cluster 1, recent evidence also supports differences between cases of EPAS1/HIF2A mosaicism and somatic EPAS1/HIF2A mutation(s) from a clinical standpoint. Patients with somatic EPASI/HIF2A mutations tend to be associated with late onset of the disease, milder clinical phenotype, and an improved prognosis compared with patients who have EPAS1/HIF2A mosaicism associated often with metastatic disease, multiplicity and recurrence [78]. 
Genotype-phenotype correlations in PPGL

As mentioned, $40 \%$ of patients carry a germline mutation in $>20$ susceptibility genes and at least $30 \%$ of sporadic cases are related to somatic mutations [27-29]. Familial PPGLs differ from their sporadic counterparts in that they are often multifocal or bilateral and are characterised by clinical presentations at young age. Since the late 90's, several hereditary PPGL syndromes have been described (Table 1). Eighty percent of the inherited PPGLs are caused by $V H L$ and $S D H-x$ germline mutations [79].

\section{Multiple Endocrine Neoplasia Type 2}

Multiple Endocrine Neoplasia type 2 (MEN2) is an autosomal dominant syndrome with an incidence of 1 in 30,000 [80]. MEN2 syndrome is causally related to activating germline mutations of the $R E T$ proto-oncogene. $R E T$ gene encodes for a tyrosine kinase receptor and is located on chromosome 10q11.21 [81, 82]. MEN2 syndrome is subdivided into MEN2A and MEN2B. Over $90 \%$ of the patients with MEN2A had a classic tumour triad: medullary thyroid carcinoma, PCC and parathyroid lesion giving rise hyperparathyroidism [83]. MEN2B is characterised by medullary thyroid carcinoma and PCC as well as mucocutaneous neuromas, gastrointestinal ganglioneuromatosis, cutaneous lichen amyloidosis and a marfanoid habitus. PCC are diagnosed in approximately $50 \%$ of MEN2 patients and often develop between the ages of 30-40 [84]. Fifty percent of the patients develop bilateral PCCs with low metastatic potential $[84,85]$.

von Hippel-Lindau disease

von Hippel-Lindau disease (VHL) is another autosomal dominant syndrome with an estimated incidence of 1 in 36,000 [86]. The VHL disease is causally related to germline mutations in the VHL tumour suppressor gene located on chromosome 3p25-26. The VHL 
disease has a very high penetrance with more than $90 \%$ of the patients developing one or more of the clinical sequelae at age 65 [87-89]. VHL is characterized by a diverse tumour spectrum of clear cell RCC and renal cysts, retinal and central nervous system hemangioblastomas, tumours of the endolymphatic sac, papillary cystadenoma of the epididymis, broad ligament and mesosalpinx, pancreatic neuroendocrine tumours and pancreatic cysts, and PPGL [90]. Approximately $20 \%$ of the patients carrying a $V H L$ mutation develop PCC, sometimes with bilateral PCC, and with a mean age at presentation of 30-year-old [91].

\section{Neurofibromatosis type 1}

Neurofibromatosis type 1 (NF1) is caused by mutations in the NF1 tumour suppressor gene on chromosome 17q11.2, which encodes for neurofibromin [92]. NF1 is an autosomal dominant condition with high penetrance and prevalence estimated at 1 in 3000 [93]. Patients with NF1 develop neurofibromas in more than $90 \%$ of the cases. PCC is an uncommon manifestation with an incidence of 5\% [90]. Although rare and sometimes bilateral, the risk of metastatic disease is relatively high (up to $12 \%$ ) in patients with NF1 $[94,95]$.

\section{Familial PPGL syndromes}

Familial PPGL syndromes are relatively new syndromes compared to MEN2, VHL and NF1 syndromes. They comprise a group of hereditary genetic disorders caused by germline mutations in $S D H-x$ tumour suppressor genes. All $S D H-x$-related syndromes are autosomal dominant and have varying penetrance rates. The genotype-phenotype correlations differ between $S D H-x$ pathogenic variants. $S D H D$ gene was the first to be identified in a PPGLaffected family [96]. Phenotype of these patients differs according to transmitting parent. In case of paternal transmission, patients will develop head and neck PGLs in more than $97 \%$ of the cases [97]. Until recently, it was considered that maternal transmission was not responsible 
for the development of PPGL and new insights show that these patients may have a lifetime risk of 5\% of developing a PPGL [98]. The median age at first tumour presentation of patients carrying $S D H D$ mutations is 33 -year-old. These patients have low risk of metastatic disease [99]. $S D H B$ mutations are found in up to $10 \%$ of the patients with PPGL and cause the development of sympathetic PGL in $60 \%$ of the cases, and head and neck PGL in $40 \%$ respectively $[28,83]$. Median age for developing PPGL in patients with $S D H B$ mutation is like patients with $S D H D$ mutation. However, patients with $S D H B$ mutated tumour have a worse prognosis and with a metastatic risk of approximately 30\% [100]. SDHA, SDHC, and SDHAF2 mutations are less common in patients with PPGL (Table 1) [77, 101, 102]. SDHC mutations often cause single head and neck PGL with a very low risk of metastasis [99]. Patients who develop PPGL due to SDHA pathogenic variants have a relatively high proportion of metastatic disease estimated approximately at $20 \%[77,103]$. In addition, patients with $S D H A, S D H B-$, SDHC- or SDHD-mutated tumours have increased risk of developing GIST, SDH-deficient RCC, and pituitary adenoma [4]. On the other hand, germline SDHAF2 mutations are only associated with head and neck PGLs without any documented non-paraganglionic tumours noted in other sites (Table 1) [104].

As discussed above, a pattern of co-existing tumours of GIST, extra-adrenal PGL and pulmonary chondroma in individuals first described by Carney et al. and later referred to as the Carney triad. Carney triad is a non-hereditary genetic disorder potentially associated with currently unknown somatic mosaicism and/or SDH genetic defects including aberrant DNA hypermethylation of $S D H C$ or, rarely, $S D H-x$ pathogenic variants $[2,72,73,105]$. In 2002, Carney and Stratakis identified a new syndrome within the group of patients with the Carney triad, who suffered from a combination of GIST and PGL [106]. This familial condition was later referred to as Carney-Stratakis dyad and is caused by germline $S D H-x$ mutations [107]. 
Hereditary leiomyomatosis and renal cell carcinoma syndrome

Hereditary leiomyomatosis and renal cell carcinoma (HLRCC) or FH tumour predisposition syndrome is caused by germline $F H$ mutations. As the name states, patients with HLRCC syndrome develop cutaneous and/or uterine leiomyomatosis as well as FH-deficient RCC. More recently, germline $F H$ mutations have been identified in patients with PPGL and subsequently these tumours expanded the HLRCC-related tumour spectrum $[108,109]$. FHassociated PPGLs are often multiple and of high metastatic potential [108].

\section{Emerging roles of molecular genetics and molecular pathology}

Over the past decade, conventional single gene sequencing has been replaced by NGS, using systems in which many genes can be analysed simultaneously. This progress is highly relevant for PPGL, in which several susceptibility genes are related to aetiopathogenesis. The American Endocrine Society and the European Society of Endocrinology both agree that patients with PPGL should be referred for genetic screening $[110,111]$. In addition, the NGS in PPGL Study Group published a consensus statement in which specific recommendations are proposed for the use of NGS in hereditary PPGL [112]. The main goal of screening is to identify patients who carry a disease-causing mutation and to test tumour tissue for the applicability of targeted therapies. NGS technologies are capable of sequencing large numbers of different DNA sequences in a single/parallel reaction [113, 114]. An often-used method for genetic screening is targeted NGS, which only targets the coding regions of genes of a specific disease using a 'panel' [115]. Now, three types of targeted NGS panels have been recommended in the diagnosis of PPGL. The first panel, described by Pillai et al., includes genes mutated at germline level and associated with hereditary disease (VHL, SDH-x, FH, MAX,NF1, RET, and TMEM127) [114]. The second is a more extended panel encompassing genes functionally relevant in PPGL (EGLN1, EPAS1, SDHAF2, KIF1B, and MET). The third is the most 
comprehensive panel, as described by Toledo et al., which includes recently identified genes at germline and/or somatic level [112]. Targeted NGS panels have made genetic screening in PPGL in individual laboratories more affordable, easy and straightforward [112]. However, this has limitations such as difficulty in adding new genes to existing panels, as well as instrument-based errors [116]. Even though targeted NGS has been established in highly specialised centres, it is not yet widely available in developing countries or less advanced clinical centres.

Whole Genome Sequencing (WGS) is a method for sequencing the whole human genome whereas whole exome sequencing (WES) is a method for sequencing only the coding regions of DNA. They are comprehensive techniques for genetic screening. WGS has the sensitivity to detect driver mutations even when they are present at very low frequency $(1 \%)$ in tumour cells [117]. However, WGS creates large amounts of data which need extensive filtering in a rather costly and complex bioinformatics analysis. WES, on the other hand, detects only sequences in the desired coding regions of DNA: the exome. It is expected that $85 \%$ of the disease-causing mutations occur within the exome, which only comprises $1 \%$ of the wholegenome [118]. WES is used to analyse all potential disease-causing genes including known susceptibility genes as well as genes unrelated to a disease. Thereby, WES can be used to identify driver mutation in PPGL with a previous negative genetic testing $[9,112]$. WES has contributed to the identification of several PPGL susceptibility genes, such as $M A X, F H$, $M D H 2, H R A S, A T R X$, and KMT2D. A limitation of WES is that promoters, enhancers, transcription factor binding sites and deep intronic sequences are not included in the analysis and hence relevant pathogenic variants would have been missed $[119,120]$. This highlights the need for WGS implementation into clinical practice.

Novel NGS techniques are RNAseq and DNA methylation profiling. RNAseq, as the term states, uses RNA instead of DNA for the analysis, which also yields expression profile 
and mutational status [114]. RNAseq can be utilised in the detection of alternative gene-spliced transcripts, posttranscriptional modifications, gene fusions, mutations/single-nucleotide polymorphisms, and alterations in gene expression. This might provide new insights in the molecular basis of PPGL, as others already have shown $[45,121]$. A downside of this technique is that analysis is more complex than targeted NGS or WES and, therefore, the implementation of RNAseq in molecular diagnostics of PPGLs is still limited [112]. Fishbein et al. analysed tumour samples using RNAseq and detected in-frame RNA fusion transcripts spanning the 5' portion of UBTF (upstream binding transcription factor) on $17 \mathrm{q} 21.31$ and the 3' portion of MAML3 on 4q31.1 [46]. These fusions are implicated in the pathogenesis of PPGL and appear to constitute a marker of aggressive disease.

DNA methylation profiling focuses on DNA methylation aberrations often present in neoplastic cells. These can display DNA hypomethylation and hypermethylation of promotor $\mathrm{CpG}$ islands with resultant transcriptional silencing of tumour suppressor genes [122]. A major advantage of DNA methylation profiling is that such DNA methylation alterations are reversible [123]. This reversibility allows for therapeutic options such as targeted drug therapies. So far, Letouze et al. and de Cubas et al. performed genome-wide DNA methylation profiling using NGS techniques in PPGLs $[59,124]$. The study by Letouze and colleagues showed that the origin of metastasis in $S D H B$-mutated PPGL was due to silencing of PNMT and KRT19 genes, which are involved in cell differentiation and epithelial-mesenchymal transition. De Cubas and co-workers found 48 novel molecular predictive markers based on DNA methylation profiling. $S D H B$-mutated tumours showed the highest levels of DNA methylation along with PNMT hypermethylation, whereas VHL- and EPASl-mutated counterparts show intermediate levels of DNA methylation. 


\section{Molecular Predictive and Prognostic Biomarkers}

While much attention has been directed at the identification of genes that are causally related to the occurrence of PPGL, there is still a lack of predictive or prognostic biomarkers, whether tissue- or serology-based [6]. In the updated WHO classification, PPGLs are now referred to as 'metastatic' or 'non-metastatic' instead of 'malignant' or 'benign' respectively, and all paraganglionic tumours are considered to have metastatic potential [125].

In a multi-disciplinary context, endocrine-related specialists need to take into consideration all the clinical, biochemical, pathological, and genetic information to make a metastatic risk prediction on an individualised basis. Ideally, the genetic profile of PPGL could be used as prognostic marker for metastatic disease with Krebs cycle gene dysregulation being highly relevant in this context. In past decade(s), many mutations have been associated with metastatic PPGL, such as SDHB, SDHA, SDHD, FH, MDH2, SLC25A11, MAX, and MAML3 $[46,108,126-131]$. Of these, $S D H B$ is the strongest genetic risk factor for metastatic PPGL, accounting for $40-50 \%$ of the cases $[128,132]$. Nevertheless, PPGL-affected patients harbouring $S D H-x$-mutations develop a metastatic phenotype only in $50 \%$ of the cases, suggesting that additional molecular mechanism(s) might play a role in metastatic progression as previously detailed in the session on molecular mechanisms in PPGL tumourigenesis [128].

As a recent example, Wilzén et al. identified recurrent mutations in $M Y C N, M Y O 5 B$ and $V C L$ genes, which co-occurred with $S D H B$ mutations in metastatic paraganglionic tumours [47]. Telomerase activation and ATRX mutations were also associated with metastatic PPGL. Fishbein and colleagues reported an association between ATRX mutations and alternate lengthening of telomeres in metastatic tumours [7]. Liu et al. and Dwight et al. showed that high TERT expression, which is associated with telomerase re-expression, is detected in metastatic PPGLs $[10,133]$. In this context, Job and co-workers displayed that transcriptional TERT activation and $A T R X$ mutations appear to be more accurate than SDHB mutations in 
discriminating metastatic PPGLs from non-metastatic counterparts, particularly in the pseudohypoxic cluster [48]. MAML3 fusion can also be utilised as predictive marker for aggressive disease with a tendency of high mutational rate in older patients [3, 46, 129].

Several studies estimated the median overall survival (OS) of patients with metastatic PPGL at 5.3 to 24.6 years (5-year OS $=62-85 \%$ and 10 -years $\mathrm{OS}=71-73 \%$ ), with significantly longer survival in case of metachronous metastases compared to synchronous ones [134-138]. Favourable prognosis has been associated with surgical resectability, female gender, younger age at diagnosis, small tumour size, head and neck PGL, low proliferative index, and less than five-fold increase in catecholamine levels.

From a genetic perspective, germline $S D H B$ mutations, somatic NF1 and MAML3 fusions, somatic SETD2 or ATRX mutations and high somatic mutation rate have been associated with unfavourable prognosis $[46,139,140]$; although the precise contributions to clinical outcome are difficult to parse. A recent meta-analysis of twenty-one studies and 703 patients with PPGL showed independent association of $S D H B$ mutation with metastasis. The median survival time for the cohort of PPGL was 240 months. In univariate analysis, survival of the patients with PPGL was correlated with both $S D H B$ mutation and metastatic stage. However, in multivariate analysis, only the presence of metastases independently correlated with patient prognosis [141]. Poor clinical outcome has also been associated with global hypermethylation, high Ki-67 labelling index [46] and aberrant TERT expression [48].

Several new types of markers have recently emerged. lncRNA evaluation analysis revealed one putative lncRNA with major reduced expression in metastatic tumours, which accurately discriminated metastatic from non-metastatic $S D H-x$-related tumours, while being an independent risk factor associated with poor clinical outcome in case of an $S D H-x$ mutation [53, 142]. Another analysis on miRNA in PPGL identified a six-miRNA signature that correlated with metastatic risk and time to progression, independent of $S D H B$ mutation status 
[55]. Hypermethylation of the $R D B P$ (negative elongation factor complex member E) promoter also appeared to be a promising biomarker of metastatic PPGL as this correlated with time to progression $[124,143]$.

Currently, cell free (cf) DNA-based methods are increasingly employed as diagnostic or screening tools for cancer detection [144]. In the context of PPGL, with extensive candidate genetic markers, cfDNA detection maybe relevant once a causative germline or somatic mutation has been identified in the primary tumour, especially in patients with increased risk of metastatic disease. However, no such studies have been performed in this patient group. 


\section{Roles of Pathology in the new era of genomic advances}

\section{ICCR guideline and risk stratification for PPGL}

Many therapeutic management decisions are based on an accurate pathology report, which is best done via standardized structured reporting and, therefore, can be applied and interpreted objectively in all patient settings [145]. The International Collaboration on Cancer Reporting (ICCR) was founded to aid and improve international benchmarking in cancer management. An ICCR Pheochromocytoma and Paraganglioma Histopathology Reporting Guide specific for resection specimens and biopsies has recently been published (http://www.iccr-cancer.org/datasets/published-datasets/endocrine/phaeochromocytoma) in 2019 and further elaborated in subsequent papers [146, 147]. In the development of the ICCR guideline, the expert panel made a distinction between "core elements" and "non-core elements". Core elements are regarded as minimum reporting requirements and are defined as essential for clinical management, staging or prognosis. Non-core elements are not considered mandatory for reporting but may be of clinical importance and recommended as good clinical practice, though not validated. The ICCR guideline consists of 16 core elements and 5 noncore elements, which are all clinical or histopathological parameters [147]. One non-core element, designated 'adverse features', takes into account risk stratification scoring systems such as the Pheochromocytoma of the Adrenal gland Scoring Scale (PASS) [148] and the Grading system for Adrenal Pheochromocytoma and Paraganglioma (GAPP) [149]. The former is specifically developed for PCC, incorporating 12 histological parameters, whereas the latter, which is more recent, is applicable for both PCC and sympathetic PGL, incorporates 4 histological parameters, immunohistochemical assessment (Ki-67 labelling index) and biochemical data (i.e. catecholamine type) and was generated for predicting metastases and grading of malignancy. A comparison study of the 2 scoring systems using 106 PCC and 37 PGL showed that higher GAPP scores were associated with aggressive PPGL [150]. On the 
other hand, PASS score was not associated with metastatic disease and demonstrated significant interobserver variability.

Although these risk stratification scoring systems are not universally adopted and not endorsed in the latest edition of World Health Organisation's volume on Endocrine Tumours, both models are potentially helpful, especially in suggesting that any particular tumour has low metastatic potential $[22,151]$. However, it is generally agreed that histological parameters are best considered in conjunction with biochemical and molecular markers. Examples of molecular markers, which have varying levels of evidence in predicting metastatic disease, include germline $S D H B$ mutations, somatic $A T R X$ and/or SETD2 mutations, TERT gene aberrancies and MAML3 fusions [151]. Pseudohypoxia Krebs cyclerelated and/or Wnt-altered molecular clusters, hypermethylation phenotype and high somatic mutational burden could also confer predictive and prognostic information [46, 151]. These markers, except for SDHB, are not yet used widely in routine clinical diagnostic setting and should be further clinically validated in prospective studies before they could be applied in risk stratification model(s) predicting metastatic potential and/or clinically aggressive disease. The current edition ( $8^{\text {th }}$ Edition) of the American Joint Committee on Cancer (AJCC) introduced a TNM staging system for neuroendocrine tumours of the adrenal gland which could be used for staging of PCC and sympathetic PGL [152]. The T staging depends on the size of the tumour, location of PPGL and invasion (T1: PCC less than 50mm and with no extra-adrenal invasion; T2: PCC of $50 \mathrm{~mm}$ or more with no extra-adrenal invasion as well as sympathetic PGL of any size; T3: tumours of any size with invasion of surrounding tissue). Apart from the standard TNM parameters, the AJCC manual recommends the collection of data such as catecholamine secretion, chromogranin A level, mitotic count and germline mutational status (SDHB mutations). Thus, some of the new pathological and molecular parameters are important in the clinical management of patients with PPGL. 


\section{Current and future roles of immunohistochemistry}

The roles of immunohistochemistry (IHC) in the pathology work-up of paraganglionic tumours are evolving [153]. Currently, these apply mostly to differential diagnosis and initial diagnostic workup, which includes Ki-67 quantitation according to the ICCR guidelines. However, genetic and predictive biomarkers are increasingly of interest.

Differential diagnosis has generally relied on demonstration of neuroendocrine markers, of which tyrosine hydroxylase is arguably the most specific, and exclusion of epithelial markers. However, keratins can be expressed focally in head and neck PGLs, which are often negative for tyrosine hydroxylase and can also be negative for generic neuroendocrine markers including chromogranin A and synaptophysin. GATA3 (GATA binding protein 3), which is a transcription factor contributing to lineage determination for both neurons and chromaffin cells, can be useful in some cases but is also expressed in parathyroid, breast, and urothelial tumours [154]. Immunoreactivity for dopamine beta-hydroxylase has been reported in a high percentage of tumours that are tyrosine hydroxylase negative [155], but this intriguing observation has not been universally observed and requires further investigation [1].

All around the world, the availability of genetic testing to identify mutations in PPGL is increasing. However, testing is currently time-consuming and expensive. The use of IHC may help in identifying underlying mutations in a cost-effective and as feasible screening approach [156]. IHC is utilised as screening tool to serve as surrogate marker for the presence of germline mutations. Dahia et al. were the first to demonstrate that SDHB protein expression is lost in hereditary PGL associated with $S D H B$ or $S D H D$ mutations [157]. Thereafter, multiple studies showed that this effect occurs in any of the hereditary tumours caused by germline $S D H$ $x$ mutations [158-160]. As the SDH subunits are linked to form the functional SDH enzyme, different $S D H-x$ mutations may cause destabilization of the complex and degradation of SDHB. 
Tumours with $S D H B, S D H C, S D H D$, or $S D H A F 2$ mutations show negative stain to SDHB protein and retain immunoreactivity for SDHA (Figure 2). On the other hand, tumours harbouring SDHA mutations lose immunoreactivity for both SDHA and SDHB. Thus, SDHA could be added into the immunohistochemical panels for detection of SDH-x mutations. SDHD IHC is generally positive in $S D H$-x mutated tumours and may help in the interpretation of inconclusive SDHB immunoexpression patterns in order to predict or validate $S D H-x$ genetic variants [161].

Another example of use of IHC is in HLRCC syndrome in which a germline $F H$ mutation leads to loss of $\mathrm{FH}$ protein expression and S-(2-succinyl) cysteine (2SC) overexpression [162]. In addition, the use of Carbonic Anhydrase IX (CAIX) immunostaining has added to the value of IHC in patients harbouring VHL mutations. Favier et al. reported positive CAIX staining in $88 \%$ of tumours with $V H L$ mutations and negative CAIX staining in $91 \%$ of tumours without $V H L$ mutation [163]. In studies of tumours with other mutations, Korpershoek and colleagues showed loss of MAX protein expression (by IHC) in MAX mutated tumours [164] (Figure 3). It is worth noting that Cheung and co-workers reported ambiguous results with regard to MAX immunoreactivity patterns in PPGLs [165].

NF1 protein immunoreactivity has also been studied in relation to NF1 mutation and was absent in the majority of the PCCs, providing a sensitivity of $66 \%$ in the detection of NF1 mutations [166]. However, negative NF1 immunoreactivity was also seen in $63 \%$ of the NF1 wild-type PCCs and, consequently, NF1 IHC had low specificity, making it an inefficient screening tool for NF1-mutated tumours. RET IHC does not seem to be of great additional value in routine diagnostic practice, as it was shown to be variably expressed in a minority of PCC tumour cells with no preference for PCC with a specific genetic background [167]. Along these lines, loss of BAP1 protein expression was demonstrated to be unrelated to genetic mutations in PPGLs [168]. 
Thus, patients with PPGL can be indirectly screened for mutations utilizing IHC complementary to the use of genetic testing. In this setting, immunohistochemical markers need to be validated in large series to become valuable in indirect genetic screening and histopathologists should be aware of limitations and pitfalls in their applicability [153]. Although NGS is the standard approach for genetic screening, IHC likely plays a vital role in validating genetic variants of unknown significance (VUS) emerging from NGS analysis. VUS is common finding in NGS and immunohistochemistry can confirm those variants with functional changes in protein expression. Papathomas et al. emphasized this need for assessing pathogenicity of VUS and further strengthened the role of SDHB/SDHA IHC in determining the functionality of VUS [159]. In addition, Wallace and colleagues showed that the combination of metabolite profiling with SDHB IHC has complementary utility in this context [169]. IHC might be indicative of whether a VUS is of any biological significance but does not assess functionality at the enzymatic level. Hence, formal evidence should be provided via functional assays for definitive categorisation.

IHC has both current and potential new roles to play both in assessing prognosis and guiding patient management. Currently used markers are the proliferative marker, Ki-67 and SDHB. SDHB is useful for both screening for mutation and risk stratification. Loss of immunoreactivity for ATRX has been reported in some PGLs and may be an immediate marker for further study [7]. Furthermore, chromogranin B has recently been shown to have a strong correlation to both the PASS score and metastasis/local recurrence. Low mRNA expression levels of chromogranin B, as well as low plasma levels and absent or weak chromogranin B immunostaining were all associated with metastasis/local recurrence [170]. IHC for somatostatin receptor $2 \mathrm{~A}$, which is expressed by most PGLs but at varying levels, can be useful in deciding whether ${ }^{68} \mathrm{GaPET} / \mathrm{CT}$ will be usefull in screening for tumor metastases [171]. An important consideration regarding IHC is that most of the molecular characterization of PPGL 
clusters has been done at the level of the transcriptome. RNA and protein levels often do not match [172], and proteins are the ultimate determinant of function. Pathologists working with IHC may therefore in many cases continue to have "the final word". 


\section{Conclusions}

The past decade has seen a rapid increase in our knowledge of the molecular pathogenesis of PPGL, spurred by the advent of whole genome-based techniques and international collaborations such as The Cancer Genome Atlas project and the International Collaboration on Cancer Reporting [173]. The number of candidate genes with germline or somatic mutations has now grown to over 20, allowing detection of germline mutations in almost $40 \%$ of patients with PPGL and somatic mutations in another $40 \%$. Thus, almost all PPGL have a known molecular basis for PPGL. In addition, with the ability to cluster these genes in subgroups, much has been learned about molecular pathogenesis of the tumours. New embryological techniques have added greatly to understanding the complex development of the human adrenal medulla and extra-adrenal paraganglia. These details may provide mechanistic insights into how the mutated genes lead to tumour development.

Now the challenge is to translate these findings into clinical practice and combine traditional pathology-based classification systems with clinical, immunohistochemical, and molecular findings to allow prognostic classification and prediction-based treatment. Overall, in upcoming years, tumour biomarkers may play a central role in PPGL. The use of molecular prognosticators will help in the identification, prognosis, and treatment of patients with metastatic PPGL. 


\section{$\underline{\text { Declarations }}$}

Funding: The authors did not receive support from any organisation for the submitted work.

Conflicts of interest: The authors have no conflicts of interest to declare that are relevant to the content of this article.

Ethics approval: Not applicable

Consent to participate: All authors consent to participate in this review

Consent for publication: All authors consent to the publication of this review

Availability of data and material: Not application for review

\section{Authors' contributions:}

T. G. Papathomas, D. P.D. Suurd, A.K. Lam and R. R. de Krijger drafted the design of the work;

T. G. Papathomas and D. P.D. Suurd performed the literature search and drafted the initial text;

K. Pacak and M. R. Vriens criticised the manuscript;

A. K. Lam and R. R. de Krijger and A.S. Tischler gave input on the concepts and finalised the manuscript;

All authors contributed to the final manuscript.

Acknowledgement: We are grateful to the invitation of the Editor-in-chief, O. Mete to coauthor this review. 


\section{References}

1. Osinga TE, Korpershoek E, de Krijger RR, et al (2015) Catecholamine-Synthesizing Enzymes Are Expressed in Parasympathetic Head and Neck Paraganglioma Tissue. Neuroendocrinology 101:289-295. https://doi.org/10.1159/000377703

2. Papathomas TG, Giordano TJ, Maher ER, Tischler AS (2019) Adrenal Glands Tumors: Pathology and Genetics. In: Boffetta P, Hainaut PBT-E of C (Third E (eds). Academic Press, Oxford, pp 18-29

3. Dahia PLM (2017) Pheochromocytomas and Paragangliomas, Genetically Diverse and Minimalist, All at Once! Cancer Cell 31:159-161. https://doi.org/10.1016/j.ccell.2017.01.009

4. Evenepoel L, Papathomas TG, Krol N, et al (2015) Toward an improved definition of the genetic and tumor spectrum associated with SDH germ-line mutations. Genet Med 17:610-620. https://doi.org/10.1038/gim.2014.162

5. Cardot-Bauters C, Carnaille B, Aubert S, et al (2019) A Full Phenotype of Paraganglioma Linked to a Germline SDHB Mosaic Mutation. J Clin Endocrinol Metab 104:3362-3366. https://doi.org/10.1210/jc.2019-00175

6. Crona J, Taïeb D, Pacak K (2017) New Perspectives on Pheochromocytoma and Paraganglioma: Toward a Molecular Classification. Endocr Rev 38:489-515. https://doi.org/10.1210/er.2017-00062

7. Fishbein L, Khare S, Wubbenhorst B, et al (2015) Whole-exome sequencing identifies somatic ATRX mutations in pheochromocytomas and paragangliomas. Nat Commun 6:6140. https://doi.org/10.1038/ncomms7140

8. Castro-Vega LJ, Letouzé E, Burnichon N, et al (2015) Multi-omics analysis defines core genomic alterations in pheochromocytomas and paragangliomas. Nat Commun 6:6044. https://doi.org/10.1038/ncomms7044

9. Toledo RA, Qin Y, Cheng Z-M, et al (2016) Recurrent Mutations of ChromatinRemodeling Genes and Kinase Receptors in Pheochromocytomas and Paragangliomas. Clin cancer Res an Off J Am Assoc Cancer Res 22:2301-2310. https://doi.org/10.1158/1078-0432.CCR-15-1841

10. Liu T, Brown TC, Juhlin CC, et al (2014) The activating TERT promoter mutation C228T is recurrent in subsets of adrenal tumors. Endocr Relat Cancer 21:427-434. https://doi.org/10.1530/ERC-14-0016

11. Papathomas TG, Oudijk L, Zwarthoff EC, et al (2014) Telomerase reverse transcriptase promoter mutations in tumors originating from the adrenal gland and extra-adrenal paraganglia. Endocr Relat Cancer 21:653-661. https://doi.org/10.1530/ERC-13-0429

12. Juhlin CC, Stenman A, Haglund F, et al (2015) Whole-exome sequencing defines the mutational landscape of pheochromocytoma and identifies KMT2D as a recurrently mutated gene. Genes Chromosomes Cancer 54:542-554. https://doi.org/10.1002/gcc.22267

13. Tischler AS, Asa SL (2019) Paraganglia. In: Mills SE (ed) Histology for Pathologists, 5th ed. Lippincott Williams and Wilkins, Philadephia, PA, USA, pp 1274-1295

14. Furlan A, Dyachuk V, Kastriti ME, et al (2017) Multipotent peripheral glial cells generate neuroendocrine cells of the adrenal medulla. Science 357: https://doi.org/10.1126/science.aal3753

15. Scriba LD, Bornstein SR, Santambrogio A, et al (2020) Cancer Stem Cells in Pheochromocytoma and Paraganglioma. Front Endocrinol (Lausanne) 11:79. https://doi.org/10.3389/fendo.2020.00079

16. Kastriti ME, Kameneva P, Kamenev D, et al (2019) Schwann Cell Precursors Generate the Majority of Chromaffin Cells in Zuckerkandl Organ and Some Sympathetic 
Neurons in Paraganglia. Front Mol Neurosci 12:6.

https://doi.org/10.3389/fnmol.2019.00006

17. Hockman D, Adameyko I, Kaucka M, et al (2018) Striking parallels between carotid body glomus cell and adrenal chromaffin cell development. Dev Biol 444 Suppl:S308S324. https://doi.org/10.1016/j.ydbio.2018.05.016

18. Schlisio S, Kenchappa RS, Vredeveld LCW, et al (2008) The kinesin KIF1Bbeta acts downstream from EgIN3 to induce apoptosis and is a potential 1p36 tumor suppressor. Genes Dev 22:884-893. https://doi.org/10.1101/gad.1648608

19. Dubard Gault M, Mandelker D, DeLair D, et al (2018) Germline SDHA mutations in children and adults with cancer. Cold Spring Harb Mol case Stud 4:.

https://doi.org/10.1101/mcs.a002584

20. $\mathrm{Wu} \mathrm{W}, \mathrm{Xu} \mathrm{WJ}$, Liu J Bin, et al (2019) Exome sequencing identifies predisposing and fusion gene in ganglioneuroma, ganglioneuroblastoma and neuroblastoma. Math Biosci Eng 16:7217-7229. https://doi.org/10.3934/mbe.2019362

21. Pozza C, Sesti F, Di Dato C, et al (2020) A Novel MAX Gene Mutation Variant in a Patient With Multiple and "Composite" Neuroendocrine-Neuroblastic Tumors. Front. Endocrinol. (Lausanne). 11:234

22. Lloyd R V, Osamura RY, Klöppel G, Rosai J (2017) WHO Classification of Tumours of Endocrine Organs. International Agency for Research on Cancer

23. Kastriti ME, Kameneva P, Adameyko I (2020) Stem cells, evolutionary aspects and pathology of the adrenal medulla: A new developmental paradigm. Mol Cell Endocrinol 518:110998. https://doi.org/10.1016/j.mce.2020.110998

24. Langley K, Grant NJ (1999) Molecular markers of sympathoadrenal cells. Cell Tissue Res 298:185-206. https://doi.org/10.1007/pl00008810

25. Lee SE, Oh E, Lee B, et al (2016) Phenylethanolamine N-methyltransferase downregulation is associated with malignant pheochromocytoma/paraganglioma. Oncotarget 7:24141-24153. https://doi.org/10.18632/oncotarget.8234

26. Fishbein L, Wilkerson MD (2018) Chromaffin cell biology: inferences from The Cancer Genome Atlas. Cell Tissue Res 372:339-346. https://doi.org/10.1007/s00441018-2795-0

27. Castro-Vega LJ, Lepoutre-Lussey C, Gimenez-Roqueplo A-P, Favier J (2016) Rethinking pheochromocytomas and paragangliomas from a genomic perspective. Oncogene 35:1080-1089. https://doi.org/10.1038/onc.2015.172

28. Buffet A, Burnichon N, Favier J, Gimenez-Roqueplo A-P (2020) An overview of 20 years of genetic studies in pheochromocytoma and paraganglioma. Best Pract Res Clin Endocrinol Metab 34:101416. https://doi.org/10.1016/j.beem.2020.101416

29. Pillai S, Gopalan V, Smith RA, Lam AK-Y (2016) Updates on the genetics and the clinical impacts on phaeochromocytoma and paraganglioma in the new era. Crit Rev Oncol Hematol 100:190-208. https://doi.org/10.1016/j.critrevonc.2016.01.022

30. Toledo RA (2017) Genetics of Pheochromocytomas and Paragangliomas: An Overview on the Recently Implicated Genes MERTK, MET, Fibroblast Growth Factor Receptor 1, and H3F3A. Endocrinol Metab Clin North Am 46:459-489. https://doi.org/10.1016/j.ecl.2017.01.009

31. Remacha L, Comino-Méndez I, Richter S, et al (2017) Targeted Exome Sequencing of Krebs Cycle Genes Reveals Candidate Cancer-Predisposing Mutations in Pheochromocytomas and Paragangliomas. Clin cancer Res an Off J Am Assoc Cancer Res 23:6315-6324. https://doi.org/10.1158/1078-0432.CCR-16-2250

32. Papathomas TG, Sun N, Chortis V, et al (2019) Novel methods in adrenal research: a metabolomics approach. Histochem Cell Biol 151:201-216.

https://doi.org/10.1007/s00418-019-01772-w 
33. Richter S, Gieldon L, Pang Y, et al (2019) Metabolome-guided genomics to identify pathogenic variants in isocitrate dehydrogenase, fumarate hydratase, and succinate dehydrogenase genes in pheochromocytoma and paraganglioma. Genet Med 21:705717. https://doi.org/10.1038/s41436-018-0106-5

34. Kim E, Wright MJ, Sioson L, et al (2017) Utility of the succinate: Fumarate ratio for assessing SDH dysfunction in different tumor types. Mol Genet Metab reports 10:4549. https://doi.org/10.1016/j.ymgmr.2016.12.006

35. Lussey-Lepoutre C, Bellucci A, Burnichon N, et al (2020) Succinate detection using in vivo (1)H-MR spectroscopy identifies germline and somatic SDHx mutations in paragangliomas. Eur J Nucl Med Mol Imaging 47:1510-1517.

https://doi.org/10.1007/s00259-019-04633-9

36. Whitworth J, Skytte A-B, Sunde L, et al (2016) Multilocus Inherited Neoplasia Alleles Syndrome: A Case Series and Review. JAMA Oncol 2:373-379.

https://doi.org/10.1001/jamaoncol.2015.4771

37. Zbuk KM, Patocs A, Shealy A, et al (2007) Germline mutations in PTEN and SDHC in a woman with epithelial thyroid cancer and carotid paraganglioma. Nat Clin Pract Oncol 4:608-612. https://doi.org/10.1038/ncponc0935

38. Gieldon L, William D, Hackmann K, et al (2019) Optimizing Genetic Workup in Pheochromocytoma and Paraganglioma by Integrating Diagnostic and Research Approaches. Cancers (Basel) 11:. https://doi.org/10.3390/cancers11060809

39. Whitworth J, Smith PS, Martin J-E, et al (2018) Comprehensive Cancer-Predisposition Gene Testing in an Adult Multiple Primary Tumor Series Shows a Broad Range of Deleterious Variants and Atypical Tumor Phenotypes. Am J Hum Genet 103:3-18. https://doi.org/10.1016/j.ajhg.2018.04.013

40. Gniado E, Carracher CP, Sharma S (2020) Simultaneous Occurrence of Germline Mutations of SDHB and TP53 in a Patient with Metastatic Pheochromocytoma. J Clin Endocrinol Metab 105:. https://doi.org/10.1210/clinem/dgz269

41. Luchetti A, Walsh D, Rodger F, et al (2015) Profiling of somatic mutations in phaeochromocytoma and paraganglioma by targeted next generation sequencing analysis. Int J Endocrinol 2015:138573. https://doi.org/10.1155/2015/138573

42. Crona J, Delgado Verdugo A, Maharjan R, et al (2013) Somatic mutations in H-RAS in sporadic pheochromocytoma and paraganglioma identified by exome sequencing. $\mathrm{J}$ Clin Endocrinol Metab 98:E1266-71. https://doi.org/10.1210/jc.2012-4257

43. Oudijk L, de Krijger RR, Rapa I, et al (2014) H-RAS mutations are restricted to sporadic pheochromocytomas lacking specific clinical or pathological features: data from a multi-institutional series. J Clin Endocrinol Metab 99:E1376-80. https://doi.org/10.1210/jc.2013-3879

44. Stenman A, Welander J, Gustavsson I, et al (2016) HRAS mutation prevalence and associated expression patterns in pheochromocytoma. Genes Chromosomes Cancer 55:452-459. https://doi.org/10.1002/gcc.22347

45. Flynn A, Benn D, Clifton-Bligh R, et al (2015) The genomic landscape of phaeochromocytoma. J Pathol 236:78-89. https://doi.org/10.1002/path.4503

46. Fishbein L, Leshchiner I, Walter V, et al (2017) Comprehensive Molecular Characterization of Pheochromocytoma and Paraganglioma. Cancer Cell 31:181-193. https://doi.org/10.1016/j.ccell.2017.01.001

47. Wilzén A, Rehammar A, Muth A, et al (2016) Malignant pheochromocytomas/paragangliomas harbor mutations in transport and cell adhesion genes. Int J cancer 138:2201-2211. https://doi.org/10.1002/ijc.29957

48. Job S, Draskovic I, Burnichon N, et al (2019) Telomerase Activation and ATRX Mutations Are Independent Risk Factors for Metastatic Pheochromocytoma and 
Paraganglioma. Clin cancer Res an Off J Am Assoc Cancer Res 25:760-770. https://doi.org/10.1158/1078-0432.CCR-18-0139

49. Tomić TT, Olausson J, Rehammar A, et al (2020) MYO5B mutations in pheochromocytoma/paraganglioma promote cancer progression. PLoS Genet 16:e1008803. https://doi.org/10.1371/journal.pgen.1008803

50. Richter S, Klink B, Nacke B, et al (2016) Epigenetic Mutation of the Succinate Dehydrogenase C Promoter in a Patient With Two Paragangliomas. J Clin Endocrinol Metab 101:359-363. https://doi.org/10.1210/jc.2015-3856

51. Haller F, Moskalev EA, Faucz FR, et al (2014) Aberrant DNA hypermethylation of SDHC: a novel mechanism of tumor development in Carney triad. Endocr Relat Cancer 21:567-577. https://doi.org/10.1530/ERC-14-0254

52. Ghosal S, Das S, Pang Y, et al (2020) Long intergenic noncoding RNA profiles of pheochromocytoma and paraganglioma: A novel prognostic biomarker. Int J cancer 146:2326-2335. https://doi.org/10.1002/ijc.32654

53. Job S, Georges A, Burnichon N, et al (2020) Transcriptome Analysis of lncRNAs in Pheochromocytomas and Paragangliomas. J Clin Endocrinol Metab 105:. https://doi.org/10.1210/clinem/dgz168

54. Yu A, Li M, Xing C, et al (2020) A Comprehensive Analysis Identified the Key Differentially Expressed Circular Ribonucleic Acids and Methylation-Related Function in Pheochromocytomas and Paragangliomas. Front Genet 11:15. https://doi.org/10.3389/fgene.2020.00015

55. Calsina B, Castro-Vega LJ, Torres-Pérez R, et al (2019) Integrative multi-omics analysis identifies a prognostic miRNA signature and a targetable miR-213p/TSC2/mTOR axis in metastatic pheochromocytoma/paraganglioma. Theranostics 9:4946-4958. https://doi.org/10.7150/thno.35458

56. Dahia PLM (2014) Pheochromocytoma and paraganglioma pathogenesis: learning from genetic heterogeneity. Nat Rev Cancer 14:108-119.

https://doi.org/10.1038/nrc3648

57. Flynn A, Dwight T, Harris J, et al (2016) Pheo-Type: A Diagnostic Gene-expression Assay for the Classification of Pheochromocytoma and Paraganglioma. J Clin Endocrinol Metab 101:1034-1043. https://doi.org/10.1210/jc.2015-3889

58. Fliedner SMJ, Shankavaram U, Marzouca G, et al (2016) Hypoxia-Inducible Factor $2 \alpha$ Mutation-Related Paragangliomas Classify as Discrete Pseudohypoxic Subcluster. Neoplasia 18:567-576. https://doi.org/10.1016/j.neo.2016.07.008

59. Letouzé E, Martinelli C, Loriot C, et al (2013) SDH Mutations Establish a Hypermethylator Phenotype in Paraganglioma. Cancer Cell 23:739-752. https://doi.org/https://doi.org/10.1016/j.ccr.2013.04.018

60. Morin A, Goncalves J, Moog S, et al (2020) TET-Mediated Hypermethylation Primes SDH-Deficient Cells for HIF2 $\alpha$-Driven Mesenchymal Transition. Cell Rep 30:45514566.e7. https://doi.org/10.1016/j.celrep.2020.03.022

61. Björklund P, Backman S (2018) Epigenetics of pheochromocytoma and paraganglioma. Mol Cell Endocrinol 469:92-97.

https://doi.org/10.1016/j.mce.2017.06.016

62. Schaefer I-M, Hornick JL, Bovée JVMG (2018) The role of metabolic enzymes in mesenchymal tumors and tumor syndromes: genetics, pathology, and molecular mechanisms. Lab Invest 98:414-426. https://doi.org/10.1038/s41374-017-0003-6

63. Ando K, Yokochi T, Mukai A, et al (2019) Tumor suppressor KIF1B $\beta$ regulates mitochondrial apoptosis in collaboration with YME1L1. Mol Carcinog 58:1134-1144. https://doi.org/10.1002/mc.22997

64. Crona J, Backman S, Welin S, et al (2018) RNA-Sequencing Analysis of 
Adrenocortical Carcinoma, Pheochromocytoma and Paraganglioma from a Pan-Cancer Perspective. Cancers (Basel) 10:. https://doi.org/10.3390/cancers10120518

65. Patterson E, Webb R, Weisbrod A, et al (2012) The microRNA expression changes associated with malignancy and SDHB mutation in pheochromocytoma. Endocr Relat Cancer 19:157-166. https://doi.org/10.1530/ERC-11-0308

66. Pillai S, Lo CY, Liew V, et al (2017) MicroRNA 183 family profiles in pheochromocytomas are related to clinical parameters and SDHB expression. Hum Pathol 64:91-97. https://doi.org/10.1016/j.humpath.2017.03.017

67. Papathomas TG, de Krijger RR, Tischler AS (2013) Paragangliomas: update on differential diagnostic considerations, composite tumors, and recent genetic developments. Semin Diagn Pathol 30:207-223.

https://doi.org/10.1053/j.semdp.2013.06.006

68. Hoekstra AS, Devilee P, Bayley J-P (2015) Models of parent-of-origin tumorigenesis in hereditary paraganglioma. Semin Cell Dev Biol 43:117-124. https://doi.org/10.1016/j.semcdb.2015.05.011

69. Yeap PM, Tobias ES, Mavraki E, et al (2011) Molecular analysis of pheochromocytoma after maternal transmission of SDHD mutation elucidates mechanism of parent-of-origin effect. J Clin Endocrinol Metab 96:E2009-13. https://doi.org/10.1210/jc.2011-1244

70. Bayley J-P, Oldenburg RA, Nuk J, et al (2014) Paraganglioma and pheochromocytoma upon maternal transmission of SDHD mutations. BMC Med Genet 15:111.

https://doi.org/10.1186/s12881-014-0111-8

71. Maher ER (2013) HIF2 and endocrine neoplasia: an evolving story. Endocr Relat Cancer 20:C5-7. https://doi.org/10.1530/ERC-13-0146

72. Carney JA (2009) Carney triad: a syndrome featuring paraganglionic, adrenocortical, and possibly other endocrine tumors. J Clin Endocrinol Metab 94:3656-3662. https://doi.org/10.1210/jc.2009-1156

73. Almeida MQ, Stratakis CA (2010) Solid tumors associated with multiple endocrine neoplasias. Cancer Genet Cytogenet 203:30-36. https://doi.org/10.1016/j.cancergencyto.2010.09.006

74. Boikos SA, Xekouki P, Fumagalli E, et al (2016) Carney triad can be (rarely) associated with germline succinate dehydrogenase defects. Eur J Hum Genet 24:569573. https://doi.org/10.1038/ejhg.2015.142

75. Settas N, Faucz FR, Stratakis CA (2018) Succinate dehydrogenase (SDH) deficiency, Carney triad and the epigenome. Mol Cell Endocrinol 469:107-111. https://doi.org/10.1016/j.mce.2017.07.018

76. Killian JK, Miettinen M, Walker RL, et al (2014) Recurrent epimutation of SDHC in gastrointestinal stromal tumors. Sci Transl Med 6:268ra177. https://doi.org/10.1126/scitranslmed.3009961

77. Bausch B, Schiavi F, Ni Y, et al (2017) Clinical Characterization of the Pheochromocytoma and Paraganglioma Susceptibility Genes SDHA, TMEM127, MAX, and SDHAF2 for Gene-Informed Prevention. JAMA Oncol 3:1204-1212. https://doi.org/10.1001/jamaoncol.2017.0223

78. Pang Y, Gupta G, Jha A, et al (2019) Nonmosaic somatic HIF2A mutations associated with late onset polycythemia-paraganglioma syndrome: Newly recognized subclass of polycythemia-paraganglioma syndrome. Cancer 125:1258-1266. https://doi.org/10.1002/cncr.31839

79. Favier J, Amar L, Gimenez-Roqueplo A-P (2015) Paraganglioma and phaeochromocytoma: from genetics to personalized medicine. Nat Rev Endocrinol 11:101-111. https://doi.org/10.1038/nrendo.2014.188 
80. Wells SAJ (2018) Advances in the management of MEN2: from improved surgical and medical treatment to novel kinase inhibitors. Endocr Relat Cancer 25:T1-T13. https://doi.org/10.1530/ERC-17-0325

81. Moline J, Eng C (2011) Multiple endocrine neoplasia type 2: an overview. Genet Med 13:755-764. https://doi.org/10.1097/GIM.0b013e318216cc6d

82. Mulligan LM (2014) RET revisited: expanding the oncogenic portfolio. Nat Rev Cancer 14:173-186. https://doi.org/10.1038/nrc3680

83. Fishbein L (2019) Pheochromocytoma/Paraganglioma: Is This a Genetic Disorder? Curr Cardiol Rep 21:104. https://doi.org/10.1007/s11886-019-1184-y

84. Wells SAJ, Asa SL, Dralle H, et al (2015) Revised American Thyroid Association guidelines for the management of medullary thyroid carcinoma. Thyroid 25:567-610. https://doi.org/10.1089/thy.2014.0335

85. Castinetti F, Qi X-P, Walz MK, et al (2014) Outcomes of adrenal-sparing surgery or total adrenalectomy in phaeochromocytoma associated with multiple endocrine neoplasia type 2: an international retrospective population-based study. Lancet Oncol 15:648-655. https://doi.org/10.1016/S1470-2045(14)70154-8

86. Richard S, Gardie B, Couvé S, Gad S (2013) Von Hippel-Lindau: how a rare disease illuminates cancer biology. Semin Cancer Biol 23:26-37. https://doi.org/10.1016/j.semcancer.2012.05.005

87. Lonser RR, Glenn GM, Walther M, et al (2003) von Hippel-Lindau disease. Lancet (London, England) 361:2059-2067. https://doi.org/10.1016/S0140-6736(03)13643-4

88. Walther MM, Reiter R, Keiser HR, et al (1999) Clinical and genetic characterization of pheochromocytoma in von Hippel-Lindau families: comparison with sporadic pheochromocytoma gives insight into natural history of pheochromocytoma. J Urol 162:659-664. https://doi.org/10.1097/00005392-199909010-00004

89. Maher ER, Neumann HP, Richard S (2011) von Hippel-Lindau disease: a clinical and scientific review. Eur J Hum Genet 19:617-623. https://doi.org/10.1038/ejhg.2010.175

90. Guilmette J, Sadow PM (2019) A Guide to Pheochromocytomas and Paragangliomas. Surg Pathol Clin 12:951-965. https://doi.org/10.1016/j.path.2019.08.009

91. Delman KA, Shapiro SE, Jonasch EW, et al (2006) Abdominal visceral lesions in von Hippel-Lindau disease: incidence and clinical behavior of pancreatic and adrenal lesions at a single center. World J Surg 30:665-669. https://doi.org/10.1007/s00268005-0359-4

92. Welander J, Söderkvist P, Gimm O (2011) Genetics and clinical characteristics of hereditary pheochromocytomas and paragangliomas. Endocr Relat Cancer 18:R25376. https://doi.org/10.1530/ERC-11-0170

93. Lammert M, Friedman JM, Kluwe L, Mautner VF (2005) Prevalence of neurofibromatosis 1 in German children at elementary school enrollment. Arch Dermatol 141:71-74. https://doi.org/10.1001/archderm.141.1.71

94. Gruber LM, Erickson D, Babovic-Vuksanovic D, et al (2017) Pheochromocytoma and paraganglioma in patients with neurofibromatosis type 1. Clin Endocrinol (Oxf) 86:141-149. https://doi.org/10.1111/cen.13163

95. Bausch B, Borozdin W, Neumann HPH (2006) Clinical and genetic characteristics of patients with neurofibromatosis type 1 and pheochromocytoma. N. Engl. J. Med. 354:2729-2731

96. Baysal BE, Ferrell RE, Willett-Brozick JE, et al (2000) Mutations in SDHD, a mitochondrial complex II gene, in hereditary paraganglioma. Science 287:848-851. https://doi.org/10.1126/science.287.5454.848

97. Burnichon N, Rohmer V, Amar L, et al (2009) The succinate dehydrogenase genetic testing in a large prospective series of patients with paragangliomas. J Clin Endocrinol 
Metab 94:2817-2827. https://doi.org/10.1210/jc.2008-2504

98. Burnichon N, Mazzella J-M, Drui D, et al (2017) Risk assessment of maternally inherited SDHD paraganglioma and phaeochromocytoma. J Med Genet 54:125-133. https://doi.org/10.1136/jmedgenet-2016-104297

99. Pasini B, Stratakis CA (2009) SDH mutations in tumorigenesis and inherited endocrine tumours: lesson from the phaeochromocytoma-paraganglioma syndromes. J Intern Med 266:19-42. https://doi.org/10.1111/j.1365-2796.2009.02111.x

100. Fliedner SMJ, Lehnert H, Pacak K (2010) Metastatic paraganglioma. Semin Oncol 37:627-637. https://doi.org/10.1053/j.seminoncol.2010.10.017

101. van der Tuin K, Mensenkamp AR, Tops CMJ, et al (2018) Clinical Aspects of SDHARelated Pheochromocytoma and Paraganglioma: A Nationwide Study. J Clin Endocrinol Metab 103:438-445. https://doi.org/10.1210/jc.2017-01762

102. Andrews KA, Ascher DB, Pires DEV, et al (2018) Tumour risks and genotypephenotype correlations associated with germline variants in succinate dehydrogenase subunit genes SDHB, SDHC and SDHD. J Med Genet 55:384-394. https://doi.org/10.1136/jmedgenet-2017-105127

103. Jha A, de Luna K, Balili CA, et al (2019) Clinical, Diagnostic, and Treatment Characteristics of SDHA-Related Metastatic Pheochromocytoma and Paraganglioma. Front Oncol 9:53. https://doi.org/10.3389/fonc.2019.00053

104. Neumann HP, Young WFJ, Krauss T, et al (2018) 65 YEARS OF THE DOUBLE HELIX: Genetics informs precision practice in the diagnosis and management of pheochromocytoma. Endocr Relat Cancer 25:T201-T219. https://doi.org/10.1530/ERC-18-0085

105. Carney JA, Sheps SG, Go VL, Gordon H (1977) The triad of gastric leiomyosarcoma, functioning extra-adrenal paraganglioma and pulmonary chondroma. N Engl J Med 296:1517-1518. https://doi.org/10.1056/NEJM197706302962609

106. Carney JA, Stratakis CA (2002) Familial paraganglioma and gastric stromal sarcoma: a new syndrome distinct from the Carney triad. Am J Med Genet 108:132-139. https://doi.org/10.1002/ajmg.10235

107. Daum O, Vanecek T, Sima R, Michal M (2006) Gastrointestinal stromal tumor: update. Klin Onkol 19:203-211

108. Castro-Vega LJ, Buffet A, De Cubas AA, et al (2014) Germline mutations in FH confer predisposition to malignant pheochromocytomas and paragangliomas. Hum Mol Genet 23:2440-2446. https://doi.org/10.1093/hmg/ddt639

109. Clark GR, Sciacovelli M, Gaude E, et al (2014) Germline FH mutations presenting with pheochromocytoma. J Clin Endocrinol Metab 99:E2046-50. https://doi.org/10.1210/jc.2014-1659

110. Lenders JWM, Duh Q-Y, Eisenhofer G, et al (2014) Pheochromocytoma and paraganglioma: an endocrine society clinical practice guideline. J Clin Endocrinol Metab 99:1915-1942. https://doi.org/10.1210/jc.2014-1498

111. Plouin PF, Amar L, Dekkers OM, et al (2016) European Society of Endocrinology Clinical Practice Guideline for long-term follow-up of patients operated on for a phaeochromocytoma or a paraganglioma. Eur J Endocrinol 174:G1-G10. https://doi.org/10.1530/EJE-16-0033

112. Toledo RA, Burnichon N, Cascon A, et al (2017) Consensus Statement on nextgeneration-sequencing-based diagnostic testing of hereditary phaeochromocytomas and paragangliomas. Nat Rev Endocrinol 13:233-247. https://doi.org/10.1038/nrendo.2016.185

113. Mardis ER (2013) Next-generation sequencing platforms. Annu Rev Anal Chem (Palo Alto Calif) 6:287-303. https://doi.org/10.1146/annurev-anchem-062012-092628 
114. Pillai S, Gopalan V, Lam AK-Y (2017) Review of sequencing platforms and their applications in phaeochromocytoma and paragangliomas. Crit Rev Oncol Hematol 116:58-67. https://doi.org/10.1016/j.critrevonc.2017.05.005

115. Welander J, Andreasson A, Juhlin CC, et al (2014) Rare Germline Mutations Identified by Targeted Next-Generation Sequencing of Susceptibility Genes in Pheochromocytoma and Paraganglioma. J Clin Endocrinol Metab 99:E1352-E1360. https://doi.org/10.1210/jc.2013-4375

116. Liu P, Li M, Guan X, et al (2018) Clinical Syndromes and Genetic Screening Strategies of Pheochromocytoma and Paraganglioma. J kidney cancer VHL 5:14-22. https://doi.org/10.15586/jkcvhl.2018.113

117. Mardis ER (2014) Sequencing the AML genome, transcriptome, and epigenome. Semin Hematol 51:250-258. https://doi.org/10.1053/j.seminhematol.2014.08.003

118. Bainbridge MN, Wang M, Burgess DL, et al (2010) Whole exome capture in solution with 3 Gbp of data. Genome Biol 11:R62. https://doi.org/10.1186/gb-2010-11-6-r62

119. Parla JS, Iossifov I, Grabill I, et al (2011) A comparative analysis of exome capture. Genome Biol 12:R97. https://doi.org/10.1186/gb-2011-12-9-r97

120. Buffet A, Calsina B, Flores S, et al (2020) Germline mutations in the new E1' cryptic exon of the VHL gene in patients with tumours of von Hippel-Lindau disease spectrum or with paraganglioma. J Med Genet. https://doi.org/10.1136/jmedgenet2019-106519

121. Cowin PA, Anglesio M, Etemadmoghadam D, Bowtell DDL (2010) Profiling the Cancer Genome. Annu Rev Genomics Hum Genet 11:133-159. https://doi.org/10.1146/annurev-genom-082509-141536

122. Jones PA, Baylin SB (2007) The epigenomics of cancer. Cell 128:683-692. https://doi.org/10.1016/j.cell.2007.01.029

123. Rodríguez-Paredes M, Esteller M (2011) Cancer epigenetics reaches mainstream oncology. Nat Med 17:330-339. https://doi.org/10.1038/nm.2305

124. de Cubas AA, Korpershoek E, Inglada-Pérez L, et al (2015) DNA Methylation Profiling in Pheochromocytoma and Paraganglioma Reveals Diagnostic and Prognostic Markers. Clin cancer Res an Off J Am Assoc Cancer Res 21:3020-3030. https://doi.org/10.1158/1078-0432.CCR-14-2804

125. Lam AK-Y (2017) Update on Adrenal Tumours in 2017 World Health Organization (WHO) of Endocrine Tumours. Endocr Pathol 28:213-227. https://doi.org/10.1007/s12022-017-9484-5

126. Comino-Méndez I, Gracia-Aznárez FJ, Schiavi F, et al (2011) Exome sequencing identifies MAX mutations as a cause of hereditary pheochromocytoma. Nat Genet 43:663-667. https://doi.org/10.1038/ng.861

127. Buffet A, Morin A, Castro-Vega L-J, et al (2018) Germline Mutations in the Mitochondrial 2-Oxoglutarate/Malate Carrier SLC25A11 Gene Confer a Predisposition to Metastatic Paragangliomas. Cancer Res 78:1914-1922. https://doi.org/10.1158/0008-5472.CAN-17-2463

128. Dahia PLM, Clifton-Bligh R, Gimenez-Roqueplo A-P, et al (2020) HEREDITARY ENDOCRINE TUMOURS: CURRENT STATE-OF-THE-ART AND RESEARCH OPPORTUNITIES: Metastatic pheochromocytomas and paragangliomas: proceedings of the MEN2019 workshop. Endocr Relat Cancer 27:T41-T52. https://doi.org/10.1530/ERC-19-0435

129. Mei L, Khurana A, Al-Juhaishi T, et al (2019) Prognostic Factors of Malignant Pheochromocytoma and Paraganglioma: A Combined SEER and TCGA Databases Review. Horm Metab Res $=$ Horm und Stoffwechselforsch $=$ Horm Metab 51:451457. https://doi.org/10.1055/a-0851-3275 
130. Calsina B, Currás-Freixes M, Buffet A, et al (2018) Role of MDH2 pathogenic variant in pheochromocytoma and paraganglioma patients. Genet Med 20:1652-1662. https://doi.org/10.1038/s41436-018-0068-7

131. Cascón A, Remacha L, Calsina B, Robledo M (2019) Pheochromocytomas and Paragangliomas: Bypassing Cellular Respiration. Cancers (Basel) 11:. https://doi.org/10.3390/cancers11050683

132. Lee H, Jeong S, Yu Y, et al (2020) Risk of metastatic pheochromocytoma and paraganglioma in SDHx mutation carriers: a systematic review and updated metaanalysis. J Med Genet 57:217-225. https://doi.org/10.1136/jmedgenet-2019-106324

133. Dwight T, Flynn A, Amarasinghe K, et al (2018) TERT structural rearrangements in metastatic pheochromocytomas. Endocr Relat Cancer 25:1-9.

https://doi.org/10.1530/ERC-17-0306

134. Hamidi O, Young WFJ, Iñiguez-Ariza NM, et al (2017) Malignant Pheochromocytoma and Paraganglioma: 272 Patients Over 55 Years. J Clin Endocrinol Metab 102:32963305. https://doi.org/10.1210/jc.2017-00992

135. Hamidi O (2019) Metastatic pheochromocytoma and paraganglioma: recent advances in prognosis and management. Curr Opin Endocrinol Diabetes Obes 26:146-154. https://doi.org/10.1097/MED.0000000000000476

136. Hamidi O, Young WFJ, Gruber L, et al (2017) Outcomes of patients with metastatic phaeochromocytoma and paraganglioma: A systematic review and meta-analysis. Clin Endocrinol (Oxf) 87:440-450. https://doi.org/10.1111/cen.13434

137. Hescot S, Curras-Freixes M, Deutschbein T, et al (2019) Prognosis of Malignant Pheochromocytoma and Paraganglioma (MAPP-Prono Study): A European Network for the Study of Adrenal Tumors Retrospective Study. J Clin Endocrinol Metab 104:2367-2374. https://doi.org/10.1210/jc.2018-01968

138. Roman-Gonzalez A, Zhou S, Ayala-Ramirez M, et al (2018) Impact of Surgical Resection of the Primary Tumor on Overall Survival in Patients With Metastatic Pheochromocytoma or Sympathetic Paraganglioma. Ann Surg 268:172-178. https://doi.org/10.1097/SLA.0000000000002195

139. Jochmanova I, Wolf KI, King KS, et al (2017) SDHB-related pheochromocytoma and paraganglioma penetrance and genotype-phenotype correlations. J Cancer Res Clin Oncol 143:1421-1435. https://doi.org/10.1007/s00432-017-2397-3

140. Eisenhofer G, Timmers HJ, Lenders JWM, et al (2011) Age at diagnosis of pheochromocytoma differs according to catecholamine phenotype and tumor location. J Clin Endocrinol Metab 96:375-384. https://doi.org/10.1210/jc.2010-1588

141. Crona J, Lamarca A, Ghosal S, et al (2019) Genotype-phenotype correlations in pheochromocytoma and paraganglioma: a systematic review and individual patient meta-analysis. Endocr Relat Cancer 26:539-550. https://doi.org/10.1530/ERC-19-0024

142. Goncalves J, Lussey-Lepoutre C, Favier J, et al (2019) Emerging molecular markers of metastatic pheochromocytomas and paragangliomas. Ann Endocrinol (Paris) 80:159 162. https://doi.org/10.1016/j.ando.2019.04.003

143. Backman S, Maharjan R, Falk-Delgado A, et al (2017) Global DNA Methylation Analysis Identifies Two Discrete clusters of Pheochromocytoma with Distinct Genomic and Genetic Alterations. Sci Rep 7:44943. https://doi.org/10.1038/srep44943

144. de Vos L, Jung M, Koerber R-M, et al (2020) Treatment Response Monitoring in Patients with Advanced Malignancies Using Cell-Free SHOX2 and SEPT9 DNA Methylation in Blood: An Observational Prospective Study. J Mol Diagn 22:920-933. https://doi.org/10.1016/j.jmoldx.2020.04.205

145. Ellis DW, Srigley J (2016) Does standardised structured reporting contribute to quality in diagnostic pathology? The importance of evidence-based datasets. Virchows Arch 
468:51-59. https://doi.org/10.1007/s00428-015-1834-4

146. Tischler A, Asa S, Clifton-Bligh R, et al (2019) Phaeochromocytoma and Paraganglioma Histopathology Reporting Guide. Sydney, Australia

147. Thompson LDR, Gill AJ, Asa SL, et al (2020) Data set for the reporting of pheochromocytoma and paraganglioma : explanations and recommendations of the guidelines from the International Collaboration on Cancer Reporting *. Hum Pathol. https://doi.org/10.1016/j.humpath.2020.04.012

148. Thompson LDR (2002) Pheochromocytoma of the Adrenal gland Scaled Score (PASS) to separate benign from malignant neoplasms: a clinicopathologic and immunophenotypic study of 100 cases. Am J Surg Pathol 26:551-566. https://doi.org/10.1097/00000478-200205000-00002

149. Kimura N, Takayanagi R, Takizawa N, et al (2014) Pathological grading for predicting metastasis in phaeochromocytoma and paraganglioma. https://doi.org/10.1530/ERC13-0494

150. Wachtel H, Hutchens T, Baraban E, et al (2020) Predicting Metastatic Potential in Pheochromocytoma and Paraganglioma: A Comparison of PASS and GAPP Scoring Systems. J Clin Endocrinol Metab 105:. https://doi.org/10.1210/clinem/dgaa608

151. Stenman A, Zedenius J, Juhlin CC (2019) The Value of Histological Algorithms to Predict the Malignancy Potential of Pheochromocytomas and Abdominal Paragangliomas - A Meta-Analysis and Systematic Review of the Literature. https://doi.org/10.3390/cancers11020225

152. Amin MB, Edge S, Greene F, et al (2017) AJCC Cancer Staging Manual, 8th ed. Springer International Publishing

153. Papathomas TG, Nosé V (2019) New and Emerging Biomarkers in Endocrine Pathology. Adv Anat Pathol 26:198-209. https://doi.org/10.1097/PAP.0000000000000227

154. Moriguchi T, Takako N, Hamada M, et al (2006) Gata3 participates in a complex transcriptional feedback network to regulate sympathoadrenal differentiation. Development 133:3871-3881. https://doi.org/10.1242/dev.02553

155. Kimura N, Miura Y, Nagatsu I, Nagura H (1992) Catecholamine synthesizing enzymes in 70 cases of functioning and non-functioning phaeochromocytoma and extra-adrenal paraganglioma. Virchows Arch A Pathol Anat Histopathol 421:25-32. https://doi.org/10.1007/BF01607135

156. Pai R, Manipadam MT, Singh P, et al (2014) Usefulness of Succinate dehydrogenase B (SDHB) immunohistochemistry in guiding mutational screening among patients with pheochromocytoma-paraganglioma syndromes. APMIS 122:1130-1135. https://doi.org/10.1111/apm.12269

157. Dahia PLM, Ross KN, Wright ME, et al (2005) A HIF1alpha regulatory loop links hypoxia and mitochondrial signals in pheochromocytomas. PLoS Genet 1:72-80. https://doi.org/10.1371/journal.pgen.0010008

158. Burnichon N, Brière J-J, Libé R, et al (2010) SDHA is a tumor suppressor gene causing paraganglioma. Hum Mol Genet 19:3011-3020. https://doi.org/10.1093/hmg/ddq206

159. Papathomas TG, Oudijk L, Persu A, et al (2015) SDHB/SDHA immunohistochemistry in pheochromocytomas and paragangliomas: a multicenter interobserver variation analysis using virtual microscopy: a Multinational Study of the European Network for the Study of Adrenal Tumors (ENS@T). Mod Pathol an Off J United States Can Acad Pathol Inc 28:807-821. https://doi.org/10.1038/modpathol.2015.41

160. van Nederveen FH, Gaal J, Favier J, et al (2009) An immunohistochemical procedure to detect patients with paraganglioma and phaeochromocytoma with germline SDHB, SDHC or SDHD gene mutations: a retrospective and prospective analysis. Lancet 
Oncol 10:764-771. https://doi.org/10.1016/S1470-2045(09)70164-0

161. Menara M, Oudijk L, Badoual C, et al (2015) SDHD Immunohistochemistry: A New Tool to Validate SDHx Mutations in Pheochromocytoma/Paraganglioma. J Clin Endocrinol Metab 100:E287-E291. https://doi.org/10.1210/jc.2014-1870

162. Skala SL, Dhanasekaran SM, Mehra R (2018) Hereditary Leiomyomatosis and Renal Cell Carcinoma Syndrome (HLRCC): A Contemporary Review and Practical Discussion of the Differential Diagnosis for HLRCC-Associated Renal Cell Carcinoma. Arch Pathol Lab Med 142:1202-1215. https://doi.org/10.5858/arpa.20180216-RA

163. Favier J, Meatchi T, Robidel E, et al (2020) Carbonic anhydrase 9 immunohistochemistry as a tool to predict or validate germline and somatic VHL mutations in pheochromocytoma and paraganglioma-a retrospective and prospective study. Mod Pathol an Off J United States Can Acad Pathol Inc 33:57-64. https://doi.org/10.1038/s41379-019-0343-4

164. Korpershoek E, Koffy D, Eussen BH, et al (2016) Complex MAX Rearrangement in a Family With Malignant Pheochromocytoma, Renal Oncocytoma, and Erythrocytosis. J Clin Endocrinol Metab 101:453-460. https://doi.org/10.1210/jc.2015-2592

165. Cheung VKY, Gill AJ, Chou A (2018) Old, New, and Emerging Immunohistochemical Markers in Pheochromocytoma and Paraganglioma. Endocr Pathol 29:169-175. https://doi.org/10.1007/s12022-018-9534-7

166. Stenman A, Svahn F, Welander J, et al (2015) Immunohistochemical NF1 analysis does not predict NF1 gene mutation status in pheochromocytoma. Endocr Pathol 26:914. https://doi.org/10.1007/s12022-014-9348-1

167. Powers JF, Brachold JM, Tischler AS (2003) Ret protein expression in adrenal medullary hyperplasia and pheochromocytoma. Endocr Pathol 14:351-361. https://doi.org/10.1385/ep:14:4:351

168. Maffeis V, Cappellesso R, Nicolè L, et al (2019) Loss of BAP1 in Pheochromocytomas and Paragangliomas Seems Unrelated to Genetic Mutations. Endocr Pathol 30:276284. https://doi.org/10.1007/s12022-019-09595-0

169. Wallace PW, Conrad C, Brückmann S, et al (2020) Metabolomics, machine learning and immunohistochemistry to predict succinate dehydrogenase mutational status in phaeochromocytomas and paragangliomas. J Pathol 251:378-387. https://doi.org/10.1002/path.5472

170. Stenman A, Svahn F, Hojjat-Farsangi M, et al (2019) Molecular Profiling of Pheochromocytoma and Abdominal Paraganglioma Stratified by the PASS Algorithm Reveals Chromogranin B as Associated With Histologic Prediction of Malignant Behavior. Am J Surg Pathol 43:409-421. https://doi.org/10.1097/PAS.0000000000001190

171. Körner M, Waser B, Schonbrunn A, et al (2012) Somatostatin receptor subtype 2A immunohistochemistry using a new monoclonal antibody selects tumors suitable for in vivo somatostatin receptor targeting. Am J Surg Pathol 36:242-252. https://doi.org/10.1097/PAS.0b013e31823d07f3

172. Koussounadis A, Langdon SP, Um IH, et al (2015) Relationship between differentially expressed mRNA and mRNA-protein correlations in a xenograft model system. Sci Rep 5:10775. https://doi.org/10.1038/srep10775

173. Pacak K, Eisenhofer G, Tischler AS (2020) Phaeochromocytoma - advances through science, collaboration and spreading the word. Nat Rev Endocrinol 16:621-622. https://doi.org/10.1038/s41574-020-00413-w 
Table 1. Genotype-phenotype correlations of phaeochromocytoma (PCC) and paraganglioma (PGL) associated with germline mutations and/or mosaicism

\begin{tabular}{|c|c|c|c|c|}
\hline Gene & $\begin{array}{l}\text { Molecular } \\
\text { Cluster }\end{array}$ & $\begin{array}{l}\text { Mutation } \\
\text { Rate }\end{array}$ & $\begin{array}{l}\text { Tumour } \\
\text { Type }\end{array}$ & $\begin{array}{c}\text { Syndromes, Tumours \& Related } \\
\text { Features }\end{array}$ \\
\hline$V H L$ & $\begin{array}{l}\text { Pseudohypoxia } \\
\text { non-Krebs cycle } \\
\text { related }\end{array}$ & $5-10 \%$ & PCC $>>$ PGL & von Hippel-Lindau disease \\
\hline $\begin{array}{l}\text { EPAS1/ } \\
\text { HIF2a }\end{array}$ & $\begin{array}{l}\text { Pseudohypoxia } \\
\text { non-Krebs cycle } \\
\text { related }\end{array}$ & $1 \%$ & PGL $>$ PCC & $\begin{array}{l}\text { PPGL-somatostatinoma- polycythaemia } \\
\text { syndrome (or Pacak-Zhuang syndrome) } \\
\text { Haemangioblastoma, Ocular } \\
\text { Manifestations i.e. dilated capillaries, } \\
\text { retinal neovascularization and fibrosis } \\
\text { overlying the optic disc }\end{array}$ \\
\hline $\begin{array}{l}\text { PHD1/ } \\
\text { EGLN2 }\end{array}$ & $\begin{array}{l}\text { Pseudohypoxia } \\
\text { non-Krebs cycle } \\
\text { related }\end{array}$ & $<1 \%$ & $\mathrm{PCC} / \mathrm{PGL}$ & $\begin{array}{l}\text { Polycythaemia with borderline or } \\
\text { mildly elevated erythropoietin levels }\end{array}$ \\
\hline $\begin{array}{l}\text { PHD2/ } \\
\text { EGLN1 }\end{array}$ & $\begin{array}{l}\text { Pseudohypoxia } \\
\text { non-Krebs cycle } \\
\text { related }\end{array}$ & $<1 \%$ & PGL/PCC & $\begin{array}{l}\text { Polycythaemia with borderline or } \\
\text { mildly elevated erythropoietin levels }\end{array}$ \\
\hline SDHA & $\begin{array}{l}\text { Pseudohypoxia } \\
\text { Krebs cycle } \\
\text { related }\end{array}$ & $<3 \%$ & PGL $>>$ PCC & $\begin{array}{c}\text { Familial PPGL SDHA-related } \\
\text { Gastrointestinal Stromal Tumour, } \\
\text { Pituitary Adenoma, SDH-deficient } \\
\text { Renal Cell Carcinoma, Neuroblastoma? }\end{array}$ \\
\hline SDHB & $\begin{array}{l}\text { Pseudohypoxia } \\
\text { Krebs cycle } \\
\text { related }\end{array}$ & $5-10 \%$ & PGL $>$ PCC & $\begin{array}{c}\text { Familial PPGL SDHB-related } \\
\text { Gastrointestinal Stromal Tumour, SDH- } \\
\text { deficient Renal Cell Carcinoma, } \\
\text { Pituitary Adenoma }\end{array}$ \\
\hline SDHC & $\begin{array}{l}\text { Pseudohypoxia } \\
\text { Krebs cycle } \\
\text { related }\end{array}$ & $<5 \%$ & PGL $>$ PCC & $\begin{array}{c}\text { Familial PPGL SDHC-related } \\
\text { Gastrointestinal Stromal Tumour, SDH- } \\
\text { deficient Renal Cell Carcinoma, } \\
\text { Pituitary Adenoma }\end{array}$ \\
\hline SDHD & $\begin{array}{l}\text { Pseudohypoxia } \\
\text { Krebs cycle } \\
\text { related }\end{array}$ & $5-10 \%$ & PGL $>$ PCC & $\begin{array}{c}\text { Familial PPGL SDHD-related } \\
\text { Gastrointestinal Stromal Tumour, SDH- } \\
\text { deficient Renal Cell Carcinoma, } \\
\text { Pituitary Adenoma, Pancreatic } \\
\text { Neuroendocrine Tumour? }\end{array}$ \\
\hline$S D H A F 2$ & $\begin{array}{l}\text { Pseudohypoxia } \\
\text { Krebs cycle } \\
\text { related }\end{array}$ & $<1 \%$ & $\mathrm{PGL}>\mathrm{PCC}$ & Familial PPGL SDHAF2-related \\
\hline $\boldsymbol{F H}$ & $\begin{array}{l}\text { Pseudohypoxia } \\
\text { Krebs cycle } \\
\text { related }\end{array}$ & $<5 \%$ & $\mathrm{PCC} / \mathrm{PGL}$ & $\begin{array}{c}\text { Hereditary Leiomyomatosis and Renal } \\
\text { Cell Carcinoma } \\
\text { (or FH tumour predisposition } \\
\text { syndrome) }\end{array}$ \\
\hline
\end{tabular}




\begin{tabular}{|c|c|c|c|c|}
\hline MDH2 & $\begin{array}{l}\text { Pseudohypoxia } \\
\text { Krebs cycle } \\
\text { related }\end{array}$ & $<1 \%$ & PGL & \\
\hline SLC25A11 & $\begin{array}{l}\text { Pseudohypoxia } \\
\text { Krebs cycle } \\
\text { related }\end{array}$ & $<1 \%$ & PGL & \\
\hline GOT2 & $\begin{array}{l}\text { Pseudohypoxia } \\
\text { Krebs cycle } \\
\text { related }\end{array}$ & $<1 \%$ & PGL & \\
\hline IDH3B & $\begin{array}{l}\text { Pseudohypoxia } \\
\text { Krebs cycle } \\
\text { related }\end{array}$ & $<1 \%$ & PGL & Acute Myeloid Leukaemia \\
\hline DNMT3A & $\begin{array}{l}\text { Pseudohypoxia } \\
\text { Krebs cycle } \\
\text { related }\end{array}$ & $<1 \%$ & PGL & Acute Myeloid Leukaemia \\
\hline DLST & $\begin{array}{l}\text { Pseudohypoxia } \\
\text { Krebs cycle } \\
\text { related }\end{array}$ & $<1 \%$ & $\mathrm{PCC} / \mathrm{PGL}$ & \\
\hline RET & $\begin{array}{c}\text { Kinase } \\
\text { Signalling }\end{array}$ & $5 \%$ & $\mathrm{PCC}>>\mathrm{PGL}$ & $\begin{array}{l}\text { Multiple Endocrine Neoplasia type } 2 \\
\text { (MEN2) syndrome }\end{array}$ \\
\hline$M E T$ & $\begin{array}{c}\text { Kinase } \\
\text { Signalling }\end{array}$ & $<1 \%$ & PCC $>$ PGL & Hereditary Papillary Renal Carcinoma \\
\hline MERTK & $\begin{array}{c}\text { Kinase } \\
\text { Signalling }\end{array}$ & $<1 \%$ & PCC/PGL & Medullary Thyroid Carcinoma \\
\hline NF1 & $\begin{array}{c}\text { Kinase } \\
\text { Signalling }\end{array}$ & $<5 \%$ & $\mathrm{PCC}>>\mathrm{PGL}$ & Neurofibromatosis 1 (NF1) syndrome \\
\hline TMEM127 & $\begin{array}{l}\text { Kinase } \\
\text { Signalling }\end{array}$ & $<5 \%$ & PCC $>$ PGL & $\begin{array}{l}\text { Familial PPGL TMEM127-related } \\
\text { Clear Cell Renal Cell Carcinoma }\end{array}$ \\
\hline $\boldsymbol{M A} \boldsymbol{X}$ & $\begin{array}{l}\text { Kinase } \\
\text { Signalling }\end{array}$ & $<5 \%$ & PCC $>$ PGL & $\begin{array}{c}\text { Familial PPGL } M A X \text {-related } \\
\text { Renal Oncocytoma, Renal Cell } \\
\text { Carcinoma, Pituitary Adenoma? } \\
\text { Pancreatic Neuroendocrine Tumour? } \\
\text { Neuroblastic Tumour(s)? }\end{array}$ \\
\hline$K I F 1 B \beta$ & $\begin{array}{c}\text { Kinase } \\
\text { Signalling }\end{array}$ & $<1 \%$ & PCC & Neuroblastoma \\
\hline$H 3 F 3 A$ & $\begin{array}{c}\text { Kinase } \\
\text { Signalling }\end{array}$ & $<1 \%$ & PCC/PGL & Giant Cell Tumour of the Bone \\
\hline$B A P 1$ & $\begin{array}{c}\text { Kinase } \\
\text { Signalling }\end{array}$ & $<1 \%$ & PGL & $B A P 1$ tumour predisposition syndrome \\
\hline MEN1 & $\begin{array}{c}\text { Kinase } \\
\text { Signalling }\end{array}$ & $<1 \%$ & PCC $>$ PGL & $\begin{array}{l}\text { Multiple Endocrine Neoplasia type } 1 \\
\text { (MEN1) syndrome }\end{array}$ \\
\hline
\end{tabular}


Table 2. Molecular clusters and associated genetic features in pheochromocytoma (PCC) and paraganglioma (PGL)

\begin{tabular}{|c|c|c|c|c|}
\hline $\begin{array}{l}\text { Molecular } \\
\text { Custer }\end{array}$ & $\begin{array}{c}\text { Phenylethanolamine- } \\
\text { N-methyltransferase } \\
(P N M T) / \\
\text { Vesicle monoamine } \\
\text { transporter (VMAT) } \\
\text { mRNA expression }\end{array}$ & Gene & $\begin{array}{c}\text { Pathway } \\
\text { Activation }\end{array}$ & $\begin{array}{c}\text { Risk of } \\
\text { Metastatic } \\
\text { Disease }\end{array}$ \\
\hline $\begin{array}{l}\text { Pseudohypoxia } \\
\text { Krebs cycle- } \\
\text { related }\end{array}$ & Low / High & $\begin{array}{c}S D H A, S D H B, \\
S D H C^{*}, S D H D, \\
S D H A F 2, F H, \\
M D H 2, \\
I D H 1^{* *}, I D H 2^{* *}, \\
I D H 3 B, G O T 2, \\
S L C 25 A 11, \\
D N M T 3 A, D L S T\end{array}$ & $\begin{array}{c}\text { Hypoxia signalling } \\
\text { pathway and epigenetic } \\
\text { modifications } \\
\text { impacting on genes } \\
\text { involved in epithelial- } \\
\text { mesenchymal transition } \\
\text { and chromaffin cell } \\
\text { differentiation and the } \\
\text { presence of } \\
\text { oncometabolites }\end{array}$ & High \\
\hline $\begin{array}{c}\text { Pseudohypoxia } \\
\text { non Krebs } \\
\text { cycle-related }\end{array}$ & Low / High & $\begin{array}{c}V H L, \\
\text { EPAS1/HIF } 2 a^{* * *}, \\
\text { PHD1/EGLN2, } \\
\text { PHD2/EGLN1, } \\
\text { IRP1** }\end{array}$ & $\begin{array}{l}\text { Hypoxia signalling } \\
\text { pathway and its target } \\
\text { genes including } \\
\text { erythropoietin (EPO) } \\
\text { and its receptor } \\
\text { (EPOR) and genes } \\
\text { related to } \\
\text { tumorigenesis }\end{array}$ & Intermediate \\
\hline $\begin{array}{l}\text { Kinase } \\
\text { signalling }\end{array}$ & High/? & $\begin{array}{c}\text { RET, MET, } \\
M E R T K, \\
N F 1^{* * * *}, \\
B R A F^{* * * * *}, \\
N G F R^{* * * * *}, \\
T M E M 127, M A X, \\
H R A S^{* *}, \\
F G F R 1^{* *}, \\
\text { KIF1B } \beta, \\
H 3 F 3 A^{* * * * * *}, \\
B A P 1, M E N 1\end{array}$ & $\begin{array}{c}\text { RAS/RAF/ERK, } \\
\text { PI3Kinase/AKT/mTOR } \\
\text { and } \\
\text { MYC/MAX/MXD1 } \\
\text { signalling pathways }\end{array}$ & Low \\
\hline $\begin{array}{c}\text { Wnt } \\
\text { altered }\end{array}$ & Low / Low & $\begin{array}{c}M A M L 3^{* * * * * *} \\
\quad C S D E 1^{* *}\end{array}$ & $\begin{array}{l}\text { Wnt/b-catenin and } \\
\text { Sonic Hedgehog } \\
\text { signalling pathways }\end{array}$ & Intermediate \\
\hline
\end{tabular}

\footnotetext{
* epimutation is also documented in addition to germline and less frequently somatic mutation

** documented only at the somatic level

*** documented at the somatic, postzygotic mosaic and germline level

**** germline and somatic mutations/fusions

$* * * * *$ fusions documented at the somatic level

$* * * * * *$ documented only at the postzygotic mosaic level
} 


\section{Figure Legends}

Fig. 1 Genetic mechanisms in PPGLs in clusters 1 and 2: Panel (A) cluster 1 genes are involved with pseudo-hypoxic pathways including $V H L, P H D 2, H I F 2 A, S D H-x, F H$ and $I D H$. Inactivation of SDH, FH and IDH are considered to cause a pseudo-hypoxic response due to accumulation of oncometabolites which in turn leads to the activation of HIF-1 $\alpha$ target genes such as EPO, VEGF, GLUT1 and P21ras implicated in the development of PPGLs. VHL and PHD2 mutations result in the absence of functional VHL protein and this further activates HIF target genes; Panel (B) cluster 2 gene mutations are associated with abnormal activation of kinase signalling pathways such as the PI3Kinase/AKT, RAS/RAF/ERK and mTOR pathways. Proteins that have been found to be altered by germline mutations in PPGLs include NF1, KIF1B $\beta$, MAX/MXD, RET, TMEM127. Activation of mTOR might constitute a common mechanism for tumour development caused by RET, MAX, or TMEM127 mutations. The role of $\mathrm{p} 53$ in the development of PPGL is poorly understood and the most likely mechanism would be evasion of apoptosis. These figures were published in "Updates on the genetics and the clinical impacts on phaeochromocytoma and paraganglioma in the new era"; 100; Pillai S, Gopalan V, Smith RA, Lam AK; Updates on the genetics and the clinical impacts on phaeochromocytoma and paraganglioma in the new era; Crit Rev Oncol Hematol. 100; 190-208; Copyright (2016), with permission from Elsevier and the corresponding author.

Fig. $2 S D H B$-mutated paraganglioma. Panel A shows the histology of a paraganglioma under haematoxylin and eosin stain. Panel B shows IHC stain for SDHB in a paraganglioma showing loss of SDHB protein in tumour cells $(\mathrm{T})$ and being retained as granular immunoreactivity in endothelial cells (black arrow) and inflammatory cells (blue arrow) (which acts as intrinsic 
controls). This tumour has particularly delicate blood vessels which are positive to. Panel C shows granular immunoreactivity for SDHA in tumour cells and endothelial cells.

Fig. 3 IHC stain for MAX in a phaeochromocytoma from a patient with a germline $M A X$ mutation. Characteristic nuclear staining of MAX is present in adrenal cortex (left upper portion) and in endothelial cells within the tumour, while the tumour cells are negative for MAX protein. 